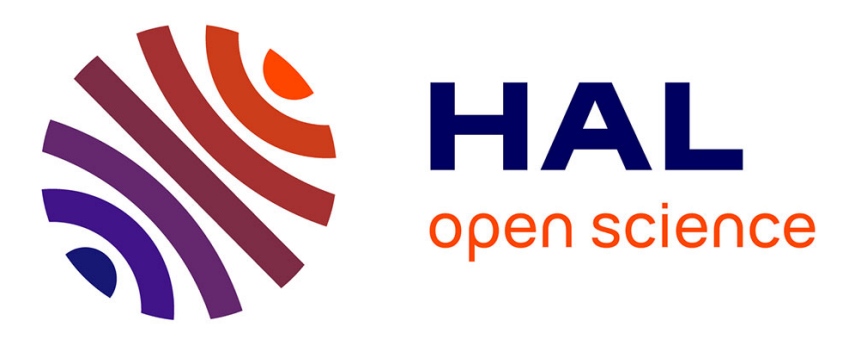

\title{
Aspiring Top Civil Servants' Distrust in the Private Sector
}

\author{
Anne Boring, Claudine Desrieux, Romain Espinosa
}

\section{To cite this version:}

Anne Boring, Claudine Desrieux, Romain Espinosa. Aspiring Top Civil Servants' Distrust in the Private Sector. Revue d'Economie Politique, 2018, 128 (6), pp.1047-1088. 10.3917/redp.286.1047 . halshs-01759358

\section{HAL Id: halshs-01759358 \\ https://shs.hal.science/halshs-01759358}

Submitted on 5 Apr 2018

HAL is a multi-disciplinary open access archive for the deposit and dissemination of scientific research documents, whether they are published or not. The documents may come from teaching and research institutions in France or abroad, or from public or private research centers.
L'archive ouverte pluridisciplinaire HAL, est destinée au dépôt et à la diffusion de documents scientifiques de niveau recherche, publiés ou non, émanant des établissements d'enseignement et de recherche français ou étrangers, des laboratoires publics ou privés. 


\title{
Aspiring top civil servants' distrust in the private sector*
}

\author{
Anne Boring $^{1}$, Claudine Desrieux ${ }^{2}$, and Romain Espinosa ${ }^{3}$ \\ ${ }^{1}$ Erasmus University Rotterdam and LIEPP, Sciences Po \\ ${ }^{2}$ CRED, Université de Paris II \\ ${ }^{3}$ CNRS - CREM, Université de Rennes I
}

April 5, 2018

\begin{abstract}
In this paper, we assess the beliefs of aspiring top civil servants towards the private sector. We use a survey conducted in a French university known for training most of the future highranking civil servants and politicians, as well as students who will work in the private sector. Our results show that students aspiring to work in the public sector are more likely to distrust the private sector, to believe that conducting business is easy, and are less likely to see the benefits of public-private partnerships. They are also more likely to believe that private sector workers are self-interested. These results have strong implications for the level of regulation in France, and the cooperation between the public and private sector.
\end{abstract}

Keywords: Public service motivation, private sector motivation, career choices, civil servants.

\section{Méfiance envers le secteur privé des aspirants hauts fonctionnaires}

\begin{abstract}
Ce travail étudie les croyances envers le secteur privé des étudiants souhaitant intégrer la haute fonction publique en France. Pour ce faire, nous analysons les données d'un sondage réalisé à Sciences Po, grand établissement français connu pour former une grande partie des hauts fonctionnaires mais aussi des étudiants souhaitant travailler dans le secteur privé. Les résultats indiquent que les étudiants souhaitant travailler dans la fonction publique font preuve d'une plus grande méfiance envers le secteur privé (comparativement aux autres étudiants), pensent davantage que diriger une entreprise est aisé, et perçoivent significativement moins de bénéfices au recours à des partenariats public-privé. Ils déclarent également plus fréquemment que les travailleurs du secteur privé sont motivés par leurs intérêts propres. Ces résultats ont de fortes implications pour comprendre le niveau de la réglementation du secteur privé en France, ainsi que la coopération entre les secteurs public et privé.
\end{abstract}

Mots clefs : Service public, Secteur privé, choix de carrière, fonction publique.

${ }^{*}$ The authors are grateful to four anonymous referees for their constructive input. 


\section{Introduction}

Government regulation of the economy is strongly and negatively correlated with trust (Aghion et al., 2010). More distrustful citizens tend to elect politicians who promote higher levels of regulation of the private sector. However, elected officials are not the only ones deciding on levels of regulation. Civil servants, especially high ranking officials, also design and enforce regulations that directly impact the private sector. ${ }^{1}$ Civil servants are different from elected officials, because they tend to remain in office when there are political changes. In many countries, and in France in particular, civil servants tend to spend their entire professional careers working in the public sector. The beliefs that these non-elected government officials have regarding the private sector are therefore likely to influence the regulations that apply to the private sector. If high-ranking civil servants have more negative beliefs regarding the private sector, they might promote higher levels of regulation than what the population would vote for through a democratic process.

In this paper, we aim to document French civil servants' beliefs regarding the private sector. To do so, we analyze how students aspiring to high-ranking positions in the public sector differ in their trust in the private sector compared to other students. Analyzing the beliefs of these aspiring civil servants is important given their future influence on the regulation of the private sector. We more specifically study whether these potential top regulators show greater distrust towards the private sector.

Our analysis relies on an original dataset that includes information collected from a survey addressed to students enrolled at Sciences Po, one of the most prestigious universities in France. Sciences $P o$ is known to be the best educational program leading to the highest positions in French higher administration. Since 2005, between $70 \%$ and $88 \%$ of the students admitted to the French National School of Administration (Ecole nationale d'administration or ENA) are former Sciences Po students. While a large share of high ranking civil servants graduated from this university, a majority of Sciences Po students choose careers in the private sector. We can therefore compare the beliefs of students who will be the future public sector leaders, with students who will work in the private sector. To measure students' beliefs, the survey includes questions that assess students' level of distrust in the private sector, how they perceive people who choose to work in the private sector, and their views regarding the private provision of public goods. We also collect information on their motivations to aim for a career in the public sector, and their trust in public institutions.

To conduct our analysis, we rely on standard statistical methods (group comparison tests), ordered response models (ordered probit and logit), and principal component analyses. Using ideal point estimation techniques, we also compare students' trust toward the private sector, and their views on how easy they think it is for entrepreneurs or firms to conduct business.

We find that students who aspire to work in the public sector: (i) tend to show more distrust in the private sector, (ii) believe that conducting business is relatively easy, (iii) are less likely to see benefits in public-private partnerships, and (iv) tend to trust public institutions more than the other students. Our results suggest that students who aspire to work in the public sector have a stronger taste for public regulation of economic activities.

These results provide some evidence of a selection bias in career choices: higher administration workers may have more negative beliefs regarding the private sector. This difference may worsen over time, given that civil servants, once in office, have limited experience of the private sector and share their offices with civil servants who hold similar beliefs. These beliefs could also complicate collaborations between the public and the private sector, for instance in the provision of public

\footnotetext{
${ }^{1}$ For instance, in France, civil servants have a large influence on the law-making process when they write the content of new laws that are debated in Parliament (Chevallier, 2011). They also have power over how new laws are to be interpreted and implemented.
} 
services.

The paper is structured as follows. Section 2 relates our work to the existing economics literature. Section 3 describes the survey and students' responses. Section 4 presents our data analyses. We conclude in section 5 .

\section{Literature}

Our paper is related to three strands of the economics literature: on the interaction between trust and regulation, on civil servants' characteristics, and on intrinsic versus extrinsic motivation of workers. In this section, we explain how our analysis connects to each of these topics.

First, our paper is inspired by the literature on the relationship between trust and regulation, as developed by Aghion et al. (2010), Cahuc and Algan (2009) and Carlin et al. (2009). The seminal work by Aghion et al. (2010) documents how government regulation is negatively correlated with trust: distrust creates public demand for regulation, and regulation discourages the formation of trust because it leads to more government ineffectiveness and corruption. They therefore show the existence of multiple equilibria, as beliefs shape institutions and institutions shape beliefs. Most of this literature relies on general measures of trust ${ }^{2}$. We adopt a different approach. Indeed, we precisely measure the level of trust towards the private sector of people aspiring to work in the public sector. Our measure is therefore more accurate to address our goal, which is to determine whether civil servants have more or less trust in the private sector than people working in the private sector. As discussed in the introduction, a higher level of civil servants' distrust in the private sector could lead to a risk of over-regulation of the private sector.

Second, our paper is related to the literature on preferences of civil servants. This literature shows that public sector workers are often more pro-social than private sector workers. For instance, Gregg et al. (2011) use data from the British Household Panel Survey to show that individuals in the non-profit sector are more likely to donate their labor (measured by unpaid overtime), compared to those in the for-profit sector. Using the American General Social Surveys, Houston (2006) finds that government employees are more likely to volunteer for charity work and to donate blood, than for-profit employees. However, he finds no difference among public service and private employees in terms of individual philanthropy. Analyzing data from the American National Election Study, Brewer (2003) shows that civil servants report higher participation in civic affairs. Using survey data from the German Socio-Economic Panel Study, Dur and Zoutenbier (2015) also find that public sector employees are significantly more altruistic than observationally equivalent private sector employees, but that they are also lazier. Finally, using revealed preferences, Buurman et al. (2012) show that public sector employees have a stronger inclination to serve others, compared to employees from the private sector. ${ }^{3}$ All these papers have post-employment choice settings. In our paper, we study beliefs regarding the private and public sectors when students are choosing their professional careers. Within the literature focusing on students, Carpenter et al. (2012) provide evidence showing that students with a strong public service orientation (evaluated by surveys addressed to American students) are more attracted to government jobs. Vandenabeele (2008) uses

\footnotetext{
${ }^{2}$ In surveys, the measure of trust is most often measured with the "generalized trust" question. This question runs as follows: "Generally speaking, would you say that most people can be trusted, or that you can't be too careful when dealing with others?" Possible answers are either "Most people can be trusted" or "Need to be very careful." The same question is used in the European Social Survey, the General Social Survey, the World Values Survey, Latinobarómetro, and the Australian Community Survey. See Algan and Cahuc (2014)

${ }^{3}$ However, when tenure increases, this difference in pro-social inclinations disappears and even reverses later on. Their results also suggest that quite a few public sector employees do not contribute to charity because they feel that they have already been contributing enough to society through work for too small a paycheck.
} 
data on students enrolled in Flemish Universities to show that students with high pro-social orientation have stronger preferences for prospective public employers. Through experiments conducted on students selected to work for the private and public sectors in Indonesia, Banuri and Keefer (2016) show that prospective entrants into the Indonesian Ministry of Finance exhibit higher levels of pro-social motivation than other students. Our paper adds to this literature, by focusing on the beliefs students have regarding the private sector, instead of measuring pro-social behavior to explain student selection of careers in the public or private sector. Our different approach is important, because individuals interested in working in the public sector may put more value on public services or exhibit more pro-social values, while showing no particular distrust towards the private sector. Alternatively, they can simultaneously show more interest in the public sector and more distrust in the private sector. Our analysis enables us to distinguish between these two possibilities, using a unique French dataset. Very few papers have investigated the possibility of self-selection of civil servants as a consequence of negative beliefs towards the private sector. Papers by Saint-Paul (2007, 2010) are an exception. They a adopt a theoretical approach to explain why individuals who are negatively biased against market economies are more likely to work in the public sector. Our approach is complementary and provides empirical evidence supporting this claim.

Finally, our paper is related to the literature on intrinsic and extrinsic motivation, as defined by Bénabou and Tirole (2003, 2006). Extrinsic motivation refers to contingent monetary rewards, while intrinsic motivation corresponds to an individual's desire to perform a task for its own sake or for the image the action conveys. Many papers have explored the consequences of intrinsic motivation in different contexts, such as on wages (Leete (2000)), knowledge transfers (Osterloh and Frey (2000)), cooperation (Kakinaka and Kotani (2011)), training (DeVaro et al. (2017)), and law enforcement (Benabou and Tirole (2011)). However, there lacks studies that analyze the extent to which values and beliefs regarding professional sectors matter when individuals choose their jobs. Our paper aims to fill this gap by exploring the different arguments that students use to explain their career choices, distinguishing between extrinsic and intrinsic motivations. In addition, we explore the beliefs of students aspiring to work in the public sector regarding the reasons why other students choose to work in the private sector.

\section{Setting and survey}

In this section, we describe the institutional context of our study (subsection 3.1). We also provide information about data collection and respondents (subsection 3.2).

\subsection{Careers of graduates}

Sciences $P o$ is a prestigious French university that specializes in social sciences. In the cohort of students who graduated in 2013 and who entered the labor market in the year following their graduation, $69 \%$ worked in the private sector, $23.5 \%$ worked in the public sector, and $7.5 \%$ worked in an international organization or a European institution. The university is especially well-known for educating France's high-ranking civil servants: a large share of the top positions in the French administration are held by Sciences Po alumni. Sciences Po is the university students attend when they ambition to get admitted to the ENA or other schools leading to high-ranking civil servant positions, and which are only open through competitive exams (concours). In the cohort of students who passed these competitive exams in 2016-17, $82 \%$ of students admitted to the ENA

were Sciences Po graduates. Sciences Po graduates also represented $67 \%$ of those admitted to top administrative positions in the National Assembly, 32\% of future hospital directors, and $57 \%$ of 
future assistant directors of the Banque de France. ${ }^{4}$ A large majority of top diplomats are also Sciences Po graduates. Sciences Po graduates therefore have a large influence on policy-making and regulation in France.

Students who graduate from this university tend to hold high-ranking positions, whether in the public or private sector. Differences in wage ambitions may partly explain students' preferences for the private sector over the public sector. While wages tend to be high for most of the public sector positions held by Sciences Po graduates, young graduates in private sector areas such as law and banking tend to earn substantially higher wages right after graduation. On the other hand, public sector jobs provide more employment security. Beliefs regarding other characteristics of each sector are likely to have a large influence on students' choices for careers. The goal of our survey is therefore to get a better understanding of how these beliefs may guide students' choices for one sector over another.

\subsection{The survey}

In order to investigate differences in students' beliefs regarding the private sector, we designed an online survey that was only accessible to students. The survey included questions on students' beliefs regarding (i) the public sector and the private sector; (ii) their classmates' views of both sectors; (iii) social relations at work, more specifically on unions and labor laws; (iv) entrepreneurship and economic regulation; and (v) a case study on public-private partnerships. The survey also included a question on students' choices for future jobs and careers.

The questionnaire was sent by the administration in mid-September 2014, two weeks after the beginning of classes, to the undergraduate and graduate students from the main campus (in Paris) and one of the satellite campuses (in Le Havre), representing a cohort of approximately 10,000 students. A total of 1,430 students completed at least part of the survey (including seven students who were not directly targeted by the survey), with approximately half of these students answering all of the questions (see Table 1 in Appendix A for a description of the sample sizes by year of study). The survey took approximately 15 minutes to complete from start to finish. Answers were recorded as students made progress through the questions, such that we are able to analyze answers to the first parts of the survey for students who did not complete it.

Among the students who completed at least part of the survey, only a few (5\%) are from the satellite undergraduate campus. Overall, $62 \%$ of respondents are Master's degree students, and 38\% are undergraduates. There are also three $\mathrm{PhD}$ students and one student preparing administrative admissions' exams who answered the survey. The share of female and male students who answered the survey is representative of the gender ratio in the overall student population ( $40 \%$ of respondents are male students, whereas the overall Sciences Po male student population was $41 \%$ in 2014). The share of respondents is similar across Master's degrees (Table 2). For instance, 19.5\% of all Master's students were in public affairs in 2014, compared to $20.6 \%$ of respondents.

A large share $(88 \%)$ of respondents are French, leading to an overrepresentation of French students. We therefore decided to drop the non-French students from our original sample. Several reasons motivated our approach. First, including non-French students in the analysis would increase the heterogeneity of respondents. Indeed, the students' answers to the questions are likely to be highly culture-dependent. The size of our dataset and the strong selection effects of foreign students prevent us from any inference from this subsample. Second, our objective is to measure the level of distrust regarding the private sector in France for prospective French civil servants. In this regard, French citizens are more likely to work in France after their graduation. Focusing on these

\footnotetext{
${ }^{4}$ http://www.sciencespo.fr/public/fr/actualites/ena-82-des-nouveaux-admis-viennent-de-sciences-po
} 
students increases the external validity of our study. Third, some questions deal specifically with French institutions, further justifying keeping only the answers submitted by French students. While foreign students may be familiar with some of these institutions (such as the Constitutional Court or the National Assembly), other institutions (such as the Conseil de Prud'hommes i.e. French labor courts), are very unlikely to be known by 20-year old foreign students. Finally, the share of students who went to high school in France and who were admitted as undergraduates (the "undergraduate national" admissions program in Table 2) are overrepresented among respondents. Indeed, they represent $41.7 \%$ of all students, but $62.3 \%$ of respondents. This overrepresentation mostly disappears when only French students are included. Indeed, $65.1 \%$ of all French students were admitted through the undergraduate national admissions procedure, whereas $69.9 \%$ of French respondents were admitted through this procedure.

The final dataset therefore includes the answers given by the 1,255 French students who completed at least part of the survey ${ }^{5}$. A total of 740 students answered the question on their professional goals: $41 \%$ of these students were considering working in the public sector, and $59 \%$ in the private sector. The data suggest that a selection bias of respondents as a function of students' study or admissions program type is unlikely (comparing columns (4) and (5) of Table 2). ${ }^{6}$

The dataset does not provide any specific information on socioeconomic background. However, $9.8 \%$ of the French students who are included in the final dataset were admitted as undergraduates through a special admissions program designed for high school students from underprivileged education zones. These students represent $9.2 \%$ of the share of the French students who responded to the survey, suggesting no significant selection bias of respondents according to this criterion.

Finally, we also checked whether our sample was representative of the overall Sciences Po student population by checking for differences in the two other observable characteristics of students, namely age and grades. Regarding age, French students who answered the survey were slightly younger than the overall French Sciences Po student population (20.5 vs. 21.1). The difference is statistically significant for both undergraduate and graduate students, but remains small in size. We checked whether this difference could be explained by the fact that the respondents were better students, and might therefore be younger. While the dataset does not provide any information on high school grades, we use students' first year undergraduate grades to compare French respondents with the overall French student population. Indeed, in the first year of undergraduate studies, the core curriculum is mandatory for all students and similar across campuses, enabling us to compare students. We know the grades of students who were Master's degree students in 2014-15, and who were first year undergraduates in 2011-12. The difference in average grades between the 227 French respondents (13.4) and the 774 French non-respondents (13.2) is weakly significant (t-test $p$-value $=0.09)^{7}$. A two-sample Kolmogorov-Smirnov test comparing the distributions of grades between students who answered the survey with the other students yields an exact p-value of 0.063. Comparing the distribution of grades for students who completed the question on professional aspirations with the other French students yields an exact $p$-value $=0.215$. The difference in average first year grades between the 253 French Master's students who were first year students in 2010-11, and the other 769 French students, is not statistically significant (13.2 for respondents, compared to 13.1 for the other French students, with a $p$-value $=0.40) .{ }^{8}$. The two-sample Kolmogorov-Smirnov tests are not statistically significant when comparing the grades of all French students with respondents

\footnotetext{
${ }^{5}$ We included only students who were on the Paris or Le Havre campuses, and who were not in an executive education program. The 1,255 observations include the responses by two students who were post-graduate students.

${ }^{6}$ In a robustness check, we further explore the issue of selection through an attrition bias. We find no effect.

${ }^{7}$ The analysis includes all French respondents.

${ }^{8}$ Some Master's students completed their undergraduate studies at another university before being admitted to Sciences Po.
} 
$(p$-value $=0.225)$ nor with the smaller sample of students who completed the question on aspirations $(p$-value $=0.198)$, suggesting no significant difference in the distribution of grades between respondents and non-respondents. Although we do not have the grades of the other respondents, the statistical evidence presented suggests that the respondents are likely to be representative of the overall French Sciences Po student population at the university.

\section{Results}

\subsection{Beliefs regarding the private sector}

Our survey enables us to investigate aspiring civil servants' perception of the private sector. The survey was addressed to all students, i.e. those aspiring to work in the public sector and those wishing to work in the private sector. This approach allows us to evaluate whether the answers of students aspiring to work in the public sector are different from the answers of the other students. We use three series of questions to evaluate students' beliefs regarding the private sector.

\subsubsection{Reasons to work in the private sector}

First, the survey asked students to report their perception of the factors that determine their classmates' motivations for careers in the private sector. The suggested motivations were the following: to work with more competent or more motivated teams (Competence and Motivation), to benefit from more work flexibility and a stronger sense of entrepreneurial spirit (Flexibility and Entrepreneurship), and to have the opportunity to earn higher wages (Wage). For each of these items, respondents could answer: Strongly Disagree, Disagree, Neither Agree nor Disagree, Agree, or Strongly Agree. We ordered these answers and assigned them numerical values from 1 (Strongly Disagree) to 5 (Strongly Agree).

Figure 1 shows the respondents' average perceptions for each of the factors driving other students to work in the private sector, according to the respondents' prospective careers. Table 3 displays the distribution of answers by students' career choices. Table 4 in further shows the results of ordered probit estimations and p-values of two-group mean-comparison tests.

First, we find that students tend to have diverging beliefs regarding the reasons that drive people to work in the private sector (Table 3). Only $28 \%$ of the students who want to take a public sector exam (strongly or weakly) agree with the fact students who plan to work in the private sector are attracted by more competent teams, compared to $42 \%$ of students who want to work in the private sector. We observe similar differences for more motivated teams (35\% vs. 49\%) and for entrepreneurial spirit (69\% vs. 88\%). However, both types of students seem to have similar beliefs regarding the attractiveness of the private sector in terms of the work flexibility (50\% vs. 51\%) and the higher wages (97\% vs. 94\%) it offers.

These results are confirmed by univariate analyses (two-group mean comparison tests and ordered probit estimates in Table 4). ${ }^{9}$ Students who aspire to become civil servants are indeed less

\footnotetext{
${ }^{9}$ We are interested in the overall difference in the beliefs of the two types of students. We therefore care about the differences between the two groups, regardless of the differences in the composition of the groups. The two groups of students might differ on several dimensions (such as social background, wealth, grades) that might explain their different beliefs regarding the private and public sectors. However, these differences of composition across students will result in differences of composition between public and private workers, which is the object of interest. We therefore estimate by univariate analyses the overall difference between prospective civil servants and private sector workers, regardless of the differences of composition.
} 
Figure 1: Average perception of factors driving students to choose the private sector according to the prospective sector of work.

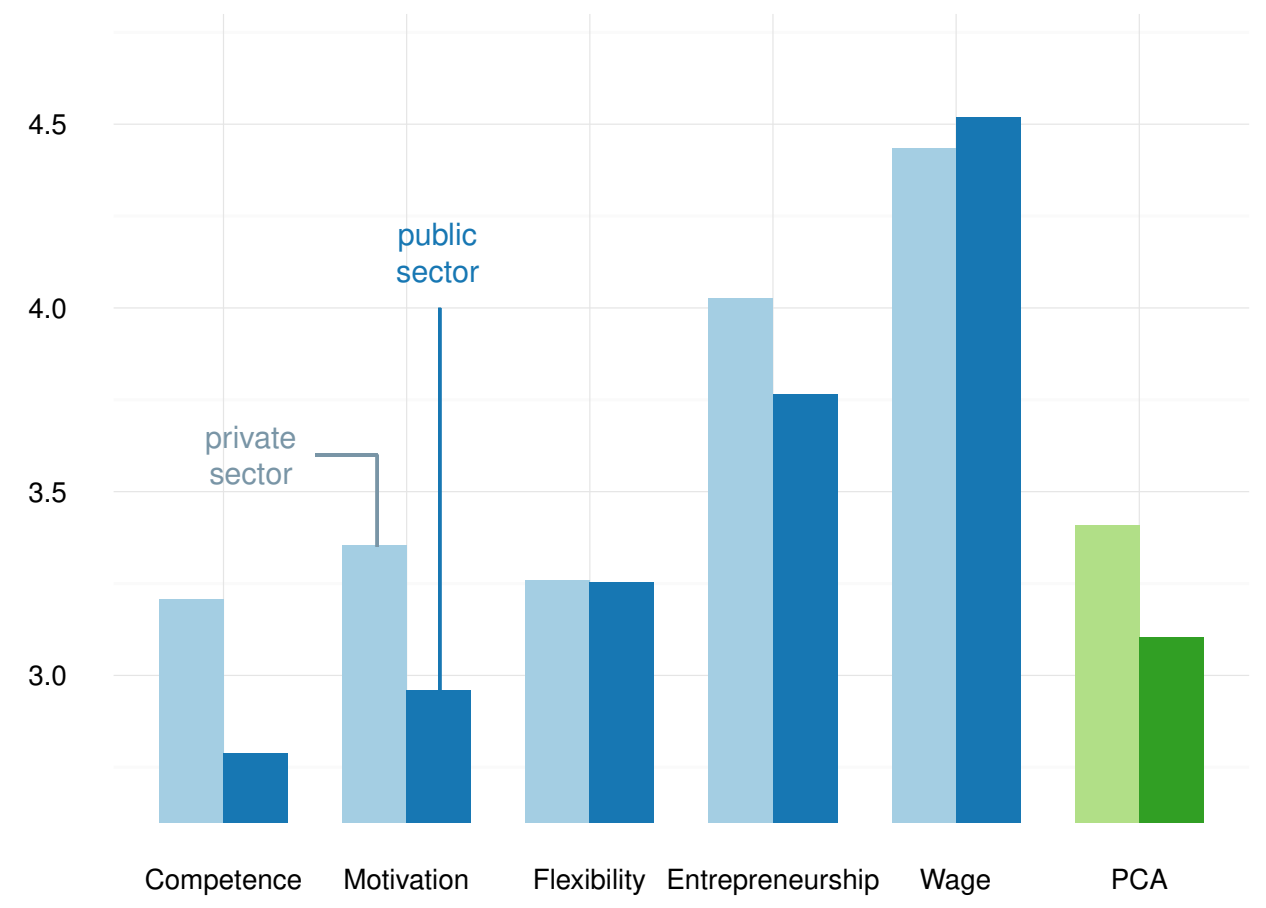

Note: Bars correspond to the average scores of each of the two groups of students for each question. Answers take values from 1 (Strongly Disagree) to 5 (Strongly Agree). The distribution of answers is presented in table 3. Full description of the questions are given in the Online Appendix.

likely to say that other students aspire to work in the private sector because of (i) greater entrepreneurial spirit $(p$-values $<0.001)$, (ii) more competent teams $(p$-values $<0.001)$, and (iii) more motivated teams $(p$-values $<0.001)$. In other words, these students have relatively more negative beliefs regarding the private sector.

To confirm the existence of latent negative beliefs regarding the reasons that drive people towards the private sector, we run a principal component analysis (PCA) on the above dimensions. The first axis of the associated PCA, which explains $38.6 \%$ of the variations, is mainly correlated with Competence, Motivation and Entrepreneurship ${ }^{10}$. Students who aspire to become civil servants show statistically higher scores on this first axis than those who want to work in the private sector. This result confirms that students interested in becoming civil servants have a worse underlying perception of the reasons that drive people to choose the private sector.

We can interpret this result in two non-mutually excluding ways. First, it might be that students who plan to become civil servants believe that other reasons than the ones listed in the survey motivate their classmates' choices. However, the list contains the main arguments usually mentioned to explain the choices for preferring the private sector over the public sector. Second, it might be that students who aspire to work in the public sector are less likely to believe that the private sector

\footnotetext{
${ }^{10}$ More specifically, we have: $\rho=0.607$ for Competence, $\rho=0.593$ for Motivation, $\rho=0.236$ for Flexibility, $\rho=0.449$ for Entrepreneurship and $\rho=0.150$ for Wage. The two dimensions that are the least correlated with the first axis (i.e., Wage and Flexibility) do not discriminate between prospective sectors of work.
} 
allows for more entrepreneurship, more competent and/or more motivated teams.

Result 1 Students who plan to work in the public sector are less likely to see entrepreneurship, competence and motivation as factors that drive other students to choose to work in the private sector.

\subsubsection{Preferences towards regulation of the private sector}

We now investigate students' preferences towards regulation of the private sector. The survey included a series of questions about the challenges that private sector companies and employees face in France. We group these questions into two dimensions. The first set of questions measures the level of Distrust in companies. We designed the second set of questions to capture students' beliefs regarding the easiness to conduct business in France today (Easy to do business). The questions associated with each set are presented below, together with a positive or negative sign to represent how answers correlate with the associated dimension.

Distrust in companies is associated with students' beliefs on whether:

- union representatives should benefit from extra protection against being fired $(+)$;

- employees should have a stronger role in the company's decision-making process $(+)$;

- controls of labor law enforcement are currently sufficient in France (-);

- thresholds above which union representation becomes mandatory in the company are too high $(+)$

- layoffs should be banned when companies make profits $(+)$;

- the government should legislate to limit employers' excessive remunerations $(+)$.

Easy to do business is associated with students' beliefs on whether:

- procedures to fire an employee should be made easier for the employer (-);

- procedures to create a new business should be made easier (-);

- procedures to hire an employee should be simplified (-);

- labor costs are contributing to high unemployment in France (-);

- it is currently easy to create a company in France $(+)$;

- it is currently easy to find funds to open a business in France $(+)$;

- it is currently easy for a young entrepreneur in France to obtain legal advice and support to start a business $(+)$.

Descriptive Statistics Tables 5 and 6 in the appendix show the distribution of answers to the questions associated with the two dimensions (Distrust in Companies and Easy to Conduct Business respectively). First, we observe that students who plan to work in the public sector have a higher tendency to distrust the private sector (Table 5). For instance, $31 \%$ of these students think that the government should legislate to limit employers' excessive remunerations, against $24 \%$ for their classmates who want to work in the private sector. Similarly, students who aspire to become civil servants are more likely to believe that controls on the enforcement of labor regulations are currently insufficient in France (52\% vs. 45\%). They are also more likely to believe in a strong support of higher levels of protection for union representatives in firms (18\% vs. $12 \%$ ).

Second, students who plan to work in the public sector are more likely to believe that conducting business in France is easy (table 6). For instance, $47 \%$ of these students weakly or strongly oppose 
reforms that would facilitate laying off employees, against $35 \%$ for their classmates who aspire to work in the private sector. Similarly, they are: (i) less likely to disagree with the statement that creating a business in France is easy (55\% vs. 60\%), (ii) more likely to believe that procedures to hire new employees should not be facilitated (10\% vs. $5 \%$ ), and (iii) more likely to believe that finding funds to open a business is easy (29\% vs. $24 \%$ ).

Ideal points To further investigate differences in beliefs between the two groups of students, we propose to locate students on the two dimensions (Distrust in companies and Easy to conduct business), using an augmented version of the graduated response model often used in ideal point estimations. Our method departs from PCA in two ways. First, we use the above definition of the dimensions to constrain the sign of the correlation between the questions and their associated dimension. For instance, we assume that a stronger support for the protection of union representatives against being laid off cannot be negatively correlated with the level of distrust in companies on the entire sample. The correlation can be either positive or null. Second, we do not consider the answers as continuous but as ordered variables. The estimation of ideal points takes into account this information to generate the two dimensions.

More specifically, we estimate the following logistic model:

$$
y_{i j}=\alpha_{j} \theta_{i}+u_{i j}
$$

where $\alpha_{j}$ is a discrimination parameter associated to question $j, \theta_{i}$ is individual $i$ 's score on the estimated dimension, and $u_{i j}$ is an idiosyncratic logistic random term. The parameter $\alpha_{j}$ represents the correlation between the question at stake and the dimension we aim to capture. The signs of the $\alpha_{j}$ are constrained by the above definition of the axes. Parameters $\theta_{i}$ represent students' opinions on the associated dimension. Higher scores for the first dimension are associated with stronger distrust in the private sector. Individuals who display higher $\theta$ s are more likely to believe that conducting business is easy. The full methodology of the estimation of the two dimensions is presented in Appendix B.

For robustness purposes, we also run PCA for each of the two dimensions, and we obtain identical results. The correlation coefficient between the first axis of the PCA and our first dimension is greater than $0.99 .^{11}$ It is equal to 0.975 for the second dimension. ${ }^{12}$

Figure 2 represents the average individual scores on the two dimensions (i.e., $\theta_{i}$ ) according to the students' willingness to work in the public sector. Table 7 in Appendix A shows the results of two-group mean-comparison tests. We find that students who plan to work in the public sector display a stronger distrust in the private sector $(p$-value $=0.088)$, and are more likely to think that conducting business in France is currently relatively easy $(p$-value $=0.017)$. Considering that our questions deal with regulation issues related to the private sector, this result implies that students who aspire to work in the public sector have a stronger taste for public regulation of economic activities.

Result 2 Students who plan to work in the public sector have a higher level of distrust in the private sector, and are more likely to believe that doing business is easy. Overall, they have a

\footnotetext{
${ }^{11}$ The first axis of the PCA explains $38.7 \%$ of the total variations. It is positively correlated with all dimensions, except for the controls on labor law enforcement, as our ideal point estimation assumes.

${ }^{12}$ The first axis of the PCA associated with the second set of variables explains $31 \%$ of the variations. The sign of the correlations between the first axis and the associated variables corresponds to the signs assumed in the ideal point estimation.
} 
Figure 2: Average attitudes towards the private sector according to the prospective sector of work.

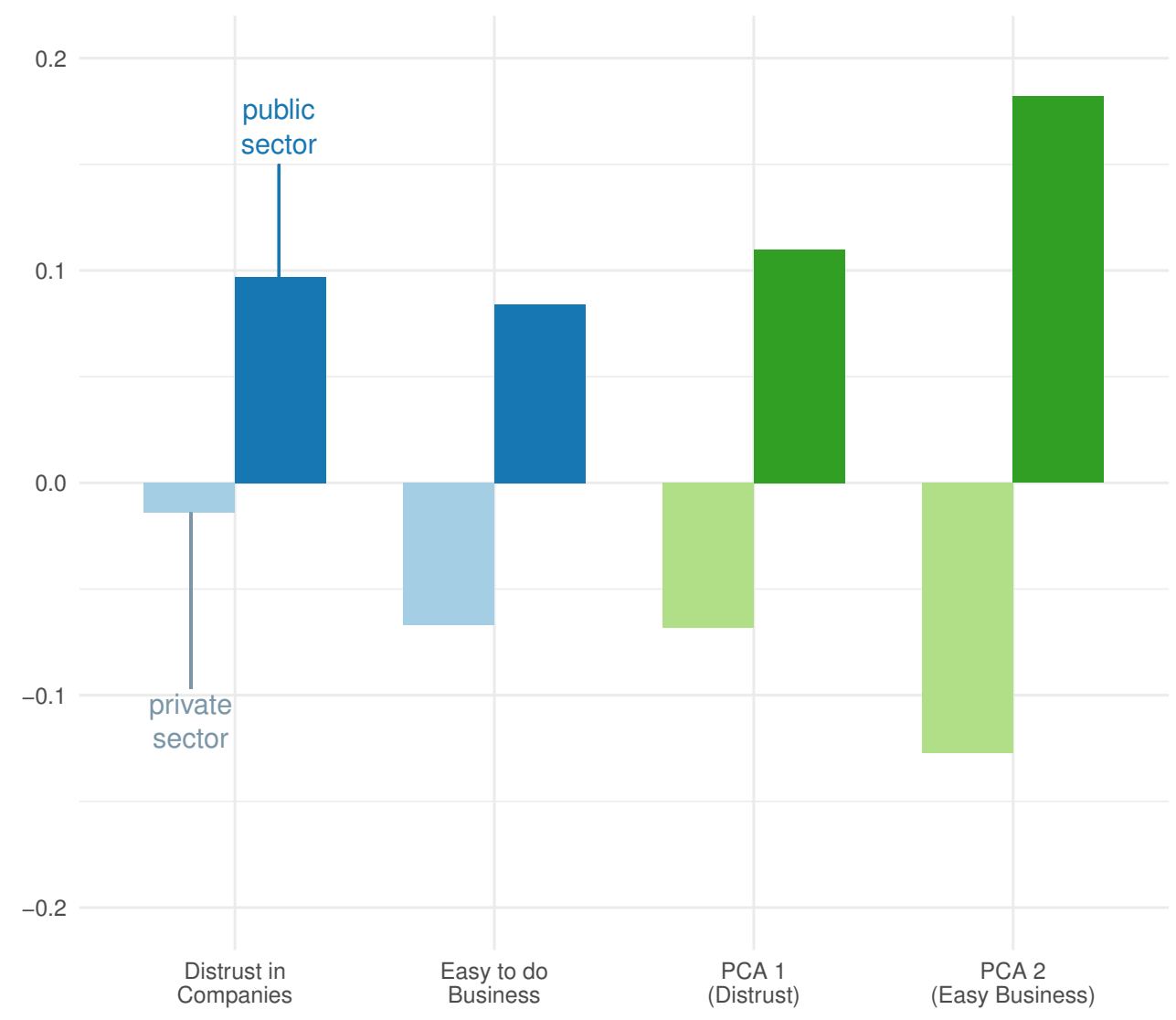

Note: Bars correspond to the average scores of each of the two groups of students for the two dimensions. The mean of each group is presented in table 7. Full description of the questions are given in the Online Appendix.

stronger taste for public regulation of economic activities.

\subsubsection{Perception of public-private partnerships}

The survey included a case study about public-private partnerships. The questions relate to students' beliefs regarding the benefits of the private provision of public goods. The questions reflect the perception of the relative advantages of the private and public sectors. The first question asked students whether they perceived delegated management of public goods as a good tool per se (Delegated Management). ${ }^{13}$ The three following questions asked students whether delegating management is a good tool to reduce management costs, to foster innovation, and to improve the quality of the services (Cost Reduction, Innovation, Quality Improvement, respectively). The following question described a conflict between the contracting public authority and its private partner, and investigated whether students perceived the public authorities' decision to expropriate the private firm as legitimate (Legitimate Expropriation). Students were then asked about the extent to

\footnotetext{
${ }^{13}$ In our context, delegated management refers to the decision of a public authority to contract out the management of a public service to a private company for a given period a time.
} 
which the State should compensate the firm for the expropriation (Damages).

The final set of questions analyzed the answers to a case about arbitration aimed at solving the conflict (instead of litigation by national courts). Students answered questions about the extent to which the arbitration decision should take into account the following arguments: the state must stick to its contractual commitments towards the firm (Commitments), the state must be allowed to nationalize sectors it considers as essential for economic growth (Nationalization), the fact that water is a vital good justifies that the state can override the contractual agreements (Necessary Good), and devaluation is a legitimate motive for the firm to increase prices (Devaluation). Finally, we run a PCA, and explain the scores on the first dimension, which represents an overall positive perception of private provision of public goods ${ }^{14}$.

Figure 3 shows the average scores for the two groups of students. Table 8 shows the distribution of answers for the questions about the relative advantages of the private provision of public goods. Table 9 in Appendix A presents the associated estimates of regression estimations and $p$-values of two-group mean-comparison tests for all items.

First, we observe a general trend: students who plan to work in the public sector are less enthusiastic about the use of public-private partnerships than their classmates who plan to work in the private sector. For instance, they are only $21 \%$ to strongly agree with the fact that publicprivate partnerships can foster innovation, against 30\% of their classmates. Similarly, only $16 \%$ strongly believe that public-private partnerships can improve the quality of the provision (vs. 25\% for students who want to work in the private sector). They are also slightly less likely to strongly believe that delegated management is a good thing (12\% vs. 15\%) and that it helps reduce costs (30\% vs. $33 \%)$.

The statistical analysis confirms these findings. Students who want to become civil servants are statistically less likely to see delegated management as improving the quality of services $(p$ value $=0.012)$ or as fostering innovation $(p$-value $=0.010)$. Moreover, they are more likely to consider expropriation as legitimate $(p$-value $=0.020)$. Third, students who plan to work in the public sector are also more likely to consider that the state must be allowed to nationalize key sectors $(p$-value $=0.002)$.

Finally, we run a PCA on all items associated to the public-private partnerships. Results show that students who aspire to become civil servants have more negative beliefs regarding the overall benefits of the private provision of public goods. The first axis of the PCA, which can be viewed as a pro-business preference for the provision of public goods ${ }^{15}$, and which explains $30 \%$ of the variations, is indeed significantly higher for students who plan to work in the private sector.

Result 3 Students who aspire to become civil servants are less likely to see benefits in the private provision of public goods, and are thus more likely to support the government in case of publicprivate partnerships.

\subsection{Beliefs regarding the public sector}

The above results suggest that students aspiring to work in the public sector tend to distrust the private sector to a greater extent. This greater distrust can either result from a general distrust in society or can be specifically targeted against the private sector. If future civil servants are more

\footnotetext{
${ }^{14}$ The first dimension is positively correlated with all variables except Legitimate Expropriation, Nationalization, and Necessary Good.

${ }^{15}$ The first axis of the PCA is indeed positively correlated with all dimensions except Legitimate Expropriation, Nationalization and Necessary Good.
} 
Figure 3: Average perception of the private provision of public goods according to the prospective sector of work.

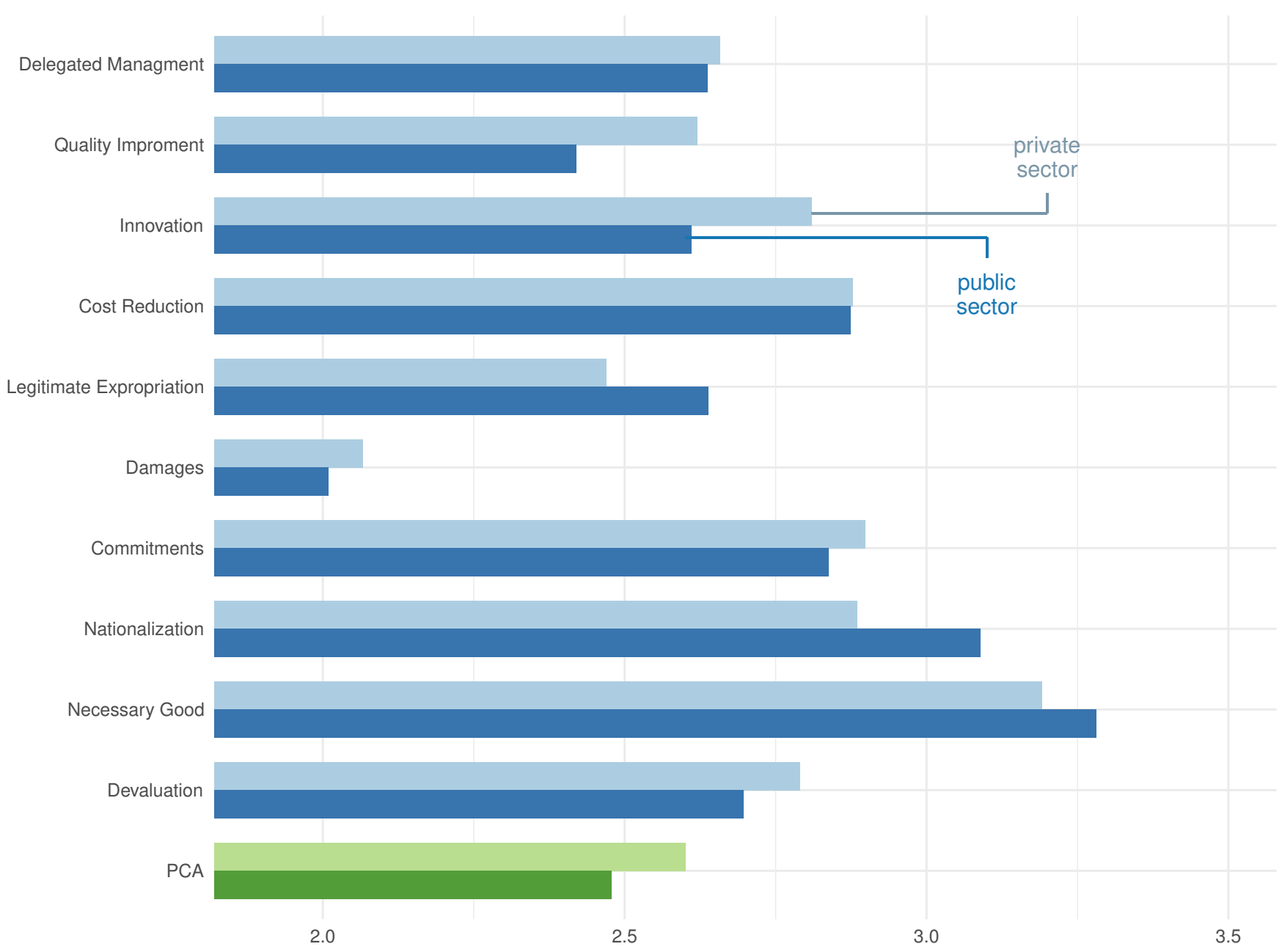

Note: Bars correspond to the average scores of each of the two groups of students for each question. Answers take values from 1 to 4 (for all items). The distribution of answers is presented in table 8. Full description of the questions are given in the Online Appendix.

distrustful in general, they may not necessarily increase the level of regulation by the state, because distrust in both sectors would offset each other. However, if they trust the public sector more than the other students, we would expect higher levels of government regulation of the private sector. Our survey therefore included questions designed to evaluate students' beliefs regarding the public sector. These questions enable us to investigate whether the relative distrust of students who aspire to become civil servants is generalized or targeted against the private sector only. We therefore investigate how students perceive the public sector, including by asking them which factors explain their choice to work as civil servants. 


\subsubsection{Trust in institutions}

Students were asked to report their level of trust on an 11-point scale (from 0-no trust to 10-total trust) for a list of seven public institutions: the Upper Chamber (Senate), the Lower Chamber (National Assembly), the police (Police), the legal system in general (Legal System), judges in general (Judges), the French Constitutional Court (Constit. Council), and the French Administrative Supreme Court (Conseil d'Etat). Figure 4 graphs the average level of trust for both types of students (i.e. those aspiring to work in the public sector, and those preferring the private sector). The two columns on the right-hand side of the graph show the average scores for the first dimension of a PCA, which represents the generalized level of trust in public institutions. ${ }^{16}$ Table 10 in Appendix A displays the summary statistics associated with these questions together with the p-value associated with the two-group mean comparison test for each variable.

Figure 4: Average level of trust in institutions according to the prospective sector of work (0 to 10 scale).

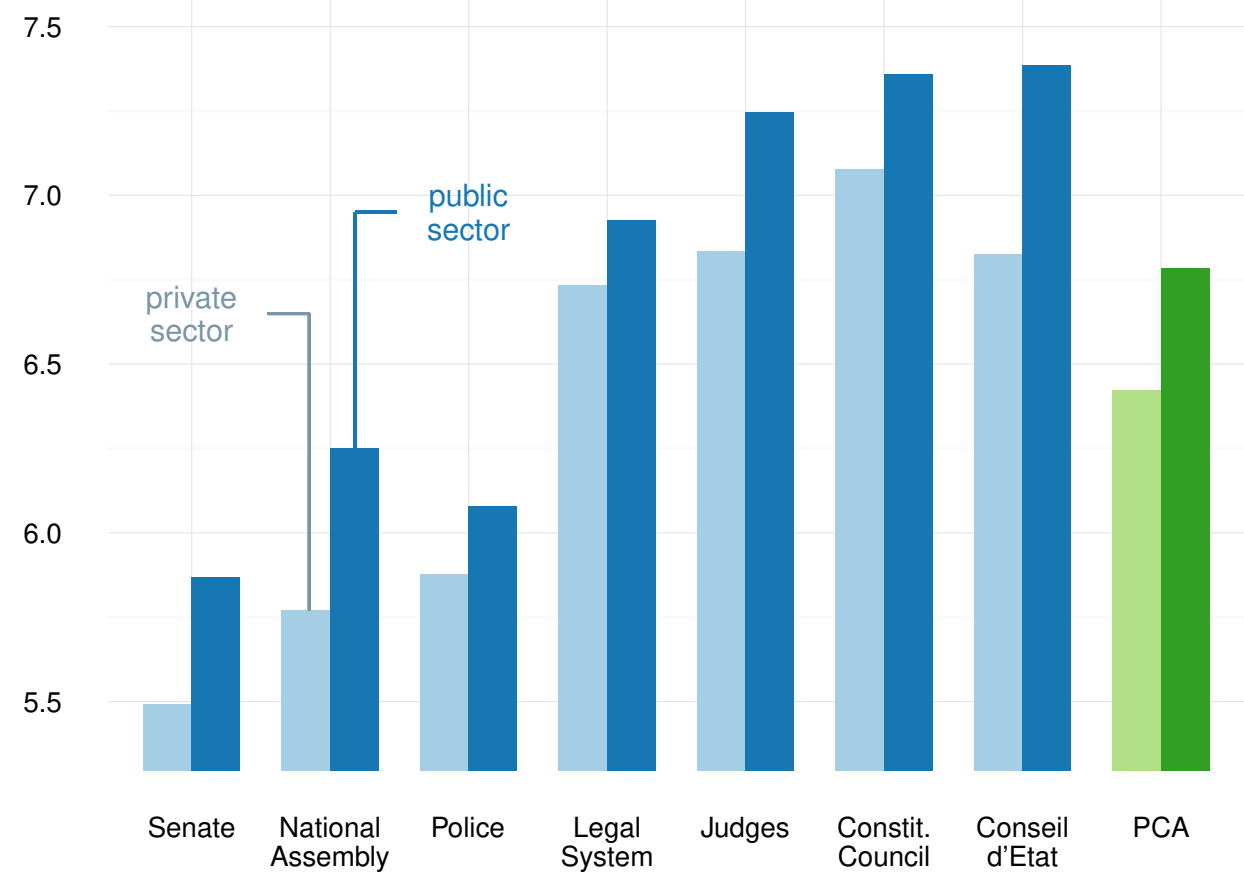

Note: Bars correspond to the average scores of each of the two groups of students for each question. Answers take values from 0 to 10 . The distribution of answers is presented in table 10. Full description of the questions are given in the Online Appendix.

First, we find that judicial institutions benefit from the highest levels of trust (Legal System, Judges, Constitutional Council and Conseil d'Etat). Political institutions and the police benefit from significantly lower levels of trust. Although this dichotomy holds for both kinds of students under scrutiny, we observe systematic higher scores for students who plan to become civil servants

\footnotetext{
${ }^{16}$ The PCA's first dimension is positively correlated with all answers (National Assembly: $\rho=0.3558$; Senate: $\rho=0.3663$; Legal System: $\rho=0.4101$; Police: $\rho=0.3103$; Judges: $\rho=0.3811$; Constitutional Council: $\rho=0.3981$; Supreme Administrative Court: $\rho=0.4136$. The first dimension explains $54.23 \%$ of the total variations.
} 
than those who aspire to careers in the private sector. Students who want to work as civil servants have higher levels of trust in the Senate (5.87 vs 5.49), the National Assembly (6.25 vs. 5.77), the Police (6.08 vs 5.88), the Legal System in general (6.93 vs. 6.73), Judges (7.25 vs. 6.84), the Constitutional Council (7.36 vs. 7.08), and the Administrative Supreme Court (7.39 vs. 6.83). The differences are statistically significant for the Lower Chamber $(p$-value $=0.002)$, the Upper Chamber $(p$-value $=0.022)$, Judges $(p$-value $=0.005)$, the Constitutional Council $(p$-value $=0.078)$, and the Administrative Supreme Court $(p$-value $<0.001)$. The first dimension of the PCA, which represents the generalized level of trust in institutions, is also significantly higher for prospective civil servants $(p$-value $=0.001)$. Although beliefs regarding the legal system in general and the police are not statistically different across students, the students aspiring to become civil servants still display a higher average level of trust. These results show that students who plan to work in the public sector do not have a generalized distrust towards society, but show distrust targeted against the private sector.

Result 4 Students who plan to become civil servants display a higher level of trust in public institutions.

\subsubsection{Reasons to become a civil servant}

To complete our analysis, we asked students about their beliefs regarding the factors that explain why individuals aspire to work in the public sector. More precisely, students were asked to report their beliefs regarding the factors that determine their classmates' choices to become civil servants. We included a list of potential benefits of being a civil servant, related to both extrinsic and intrinsic motivation. Among the extrinsic motivation factors, we suggested a lower workload (Lower Workload), a more convenient family life (Easy Family), and greater job security (Greater Security). For intrinsic motivation, we suggested the following factors: a source of social gratification (Social Gratification), more opportunities to change society (Change Society), and personal satisfaction of being involved in public affairs (Satisfaction).

Figure 5 shows the average scores for each group of students, ranking the answers from 1 (Strongly Disagree) to 5 (Strongly Agree). Table 11 shows the distribution of answers according to career aspirations. Table 12 presents the results of ordered probit estimations and the $p$-values of two-group mean-comparison tests.

Students who aspire to become civil servants are more likely to believe that pro-social reasons are driving their classmates' choices for the public sector. The estimations indicate that students who aspire to work in the public sector are more likely to believe that their classmates choose to become civil servants (i) for the satisfaction of being involved in public affairs $(84 \%$ mildly or strongly agree vs. $73 \%$ for students who want to work in the private sector, p-values $<0.001)$, and (ii) for the opportunities they have to change society $(74 \%$ vs. $63 \%, p$-values $<0.001)$. On the contrary, students who do not plan to become civil servants are more likely to believe that their classmates are interested in working in the public sector for self-concerned reasons, i.e. the lower workload (19\% vs. $13 \%$, p-values $<0.001)$, and the convenience to organize family life (only $33 \%$ disagree vs. $43 \%$ of future civil servants disagree, $p$-value $=0.105$ for the ordered probit estimation, and $p$-value $=0.085$ for the two-group mean-comparison test).

Finally, we run a PCA on these six dimensions. The first axis, which explains $35 \%$ of the variations, is positively correlated with the pro-social motivations to choose the public sector (i.e. Satisfaction $(\rho=0.392)$, Social Gratification $(\rho=0.36)$, Change Society $(\rho=0.386))$, depicted in blue in Figure 5, and negatively with the self-concerned motivations (i.e. Greater Job Security $(\rho=-0.247)$, Lower Workload $(\rho=-0.516)$, More Convenient Family Life $(\rho=-0.49))$, depicted 
Figure 5: Average perception of factors driving students to choose the public sector according to the prospective sector of work.

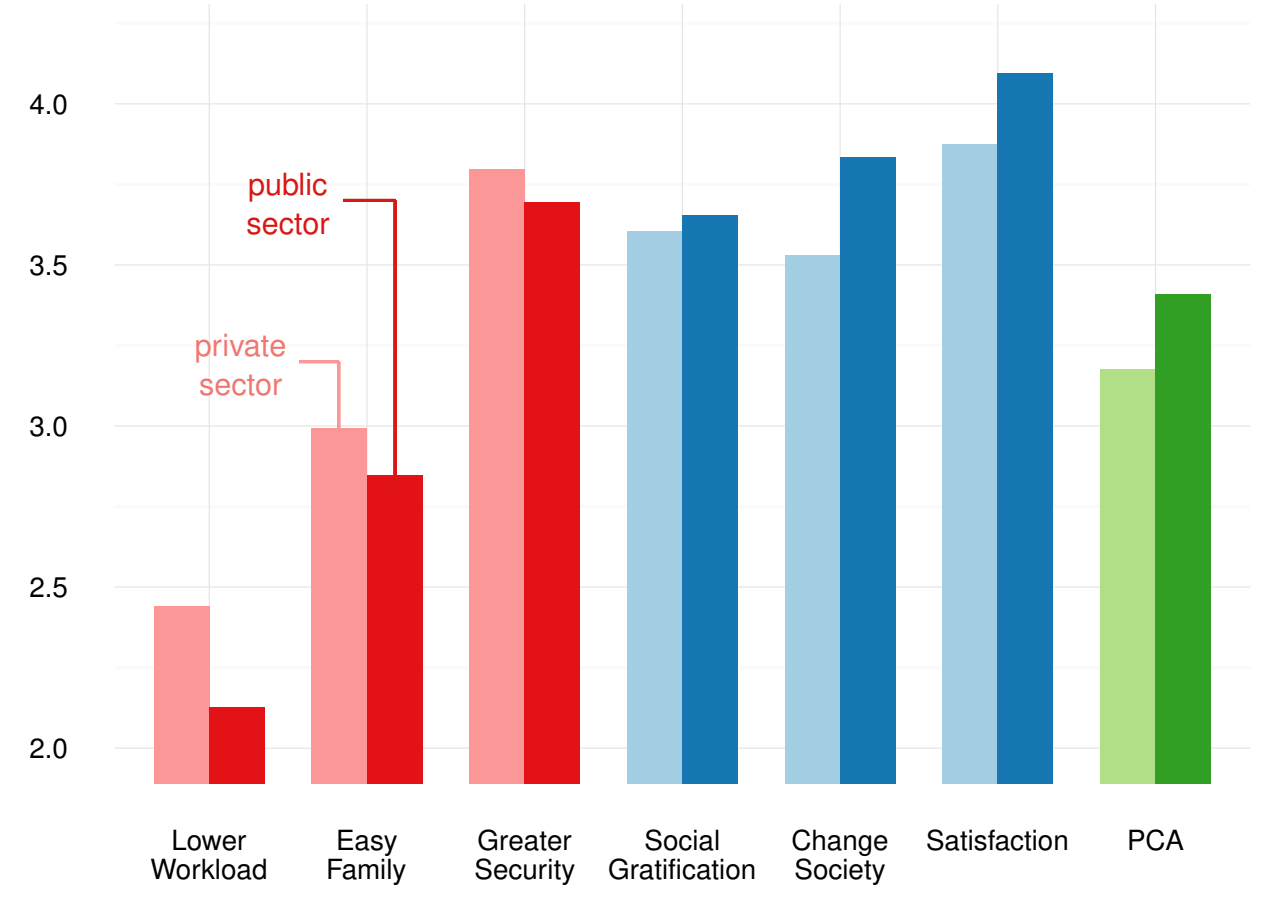

Note: Bars correspond to the average scores of each of the two groups of students for each question. Answers take values from 1 (Strongly Disagree) to 5 (Strongly Agree). The distribution of answers is presented in table 11. Full description of the questions are given in the Online Appendix.

in red in Figure 5. The comparison of the PCA scores of the two types of students shows that, on average, students aspiring to a career in the public sector are more likely than their classmates to think that students aspire to become civil servants for pro-social reasons ( $p$-value $<0.001)$.

Result 5 Both types of students recognize that people aspiring to work in the public sector generally do so for pro-social reasons (i.e. the satisfaction of being involved in public affairs, and the opportunity to change society). However, this result is stronger for students who want to become public servants. Students who plan to work in the private sector are more likely to believe that their classmates aspire to careers in the public sector for self-concerned reasons (i.e. lower workload, more convenient family life).

\subsection{Robustness Checks}

The survey contained questions about the perception of the public and the private sectors, and students' aspiration to work in the public sector after graduation. The fact that both the dependent and the independent variables were obtained from the same survey might generate some methodological concerns, usually referred to as the Common Source Bias (CSB). In our case, we are not able to rule out the possibility that participants sought to reduce cognitive dissonance or to improve / protect self-image by aligning their answers. Nevertheless, the impact of the CSB is limited by 
the fact that questions were asked on successive screens, and that half of the dimensions discussed above were explored before participants were asked about their personal professional aspirations. Moreover, the aspiration to work in the public sector was obtained by asking whether participants intended to take exams to enter the public sector. Given the long preparation that these exams require, it seems unlikely that previous declarations about the attractiveness of each sector affected participants' declaration about their intention to take these exams.

In order to test the robustness of our results to the CSB, we use respondents' identifier to retrieve the Master's program of graduate students. We then associate to each graduate student the average proportion of students registered in his/her graduate school who ended up working in the private sector (based on the post-graduation employment survey of students who graduated in 2015). This measure reflects the average ex-post propensity to really work in the private sector, and is not subject to the CSB. We observe that this variable is highly correlated with the individual declarations in the survey $(\hat{\rho}=0.468, p<0.001)$. We run all the previous estimations replacing the potentially biased self-declaration by this exogenous measure. We cluster observations at the graduate school level given the level of aggregation of information. The new results, displayed in table 13, lose in statistical significance, mostly because of the reduction in the variance in the explanatory variable and in the degrees of freedom, but confirm the above results. Indeed, individuals with higher chances of working in the public sector trust public institutions (National Assembly, Senate, Judges, Administrative Supreme Court) significantly more, are more likely to believe that public servants work in the public sector for noble reasons (Gratification, Change) and less likely to believe they do so for the potentially lower workload (Workload). They are also less likely to believe that students who want to work in the private sector plan to do so because of greater entrepreneurial spirit. They are also more likely to believe that unionists should be more protected against employers. Moreover, in the case of public-private partnerships, they are more likely to find that government intervention is legitimate, and they are more likely to accept nationalization.

Attrition Bias The survey included five successive sections. A non-negligible proportion of respondents answered only part of it. Students who did not complete the survey may represent a specific subset of the population, such that students who answered the last set of questions may not be representative of the set of students who started the survey but quit before the end. To investigate whether attrition in the survey changed the composition of respondents over the different sections, we regress each of our dependent variables on the number of sections the respondents completed. Should an attrition bias on the dependent variable emerge, we would observe a significant coefficient associated with the number of screens. For instance, if the least trustful students stopped answering first, we would observe that the level of trust in public institutions (first screen of the survey) significantly increases with the number of screens completed.

Implementing this strategy over 25 dependent variables, we obtain only three significant relationships (two at $10 \%$ and one at 1\%). Assuming that there is no attribution effect (i.e., that the dependent variables are not correlated with the number of completed screens), the probability to have at least 3 out of 25 regressions in which the coefficient is significant at $10 \%$ equals $20.5 \%{ }^{17}$ Therefore, we are not able to reject the hypothesis of no attrition effect regarding the dependent variables.

\footnotetext{
${ }^{17}$ The probability of no significant relationship is $\left(\frac{9}{10}\right)^{25}$. The probability of one significant relationship is $\frac{25 !}{(25-1) !} \frac{1}{10}\left(\frac{9}{10}\right)^{24}$. The probability of two significant relationships is $\frac{25 !}{(25-2) !}\left(\frac{1}{10}\right)^{2}\left(\frac{9}{10}\right)^{23}$. The probability of at least three significant relationships at $10 \%$ equals 1 minus the sum of these three probabilities, which is $p=20.5 \%$.
} 


\section{Conclusion}

Our results suggest that future civil servants distrust the private sector to a greater extent than the other students. They also believe that conducting business is relatively easy, and are less likely to see benefits in public-private partnerships. These results provide some evidence of a selection effect in career choices: individuals working in the public sector hold more negative beliefs regarding the private sector. Our evidence also suggests that this distrust is more specifically targeted towards the private sector and is not generalized: future civil servants show high level of trust regarding public institutions.

Civil servants' distrust towards the private sector has strong implications in terms of political economy. First, civil servants are in charge of the design and implementation of regulation. Their distrust of the private sector may lead to its over-regulation, therefore generating difficulties in conducting business. The 2018 Doing Business report edited by the World Bank provides evidence of these difficulties. This report provides objective measures of business regulations and their enforcement across 190 economies. It captures several important dimensions of the regulatory environment as it applies to local firms. ${ }^{18}$ The global indicator that accounts for this regulatory environment is called "Ease of Doing Business". Each country is evaluated through its distance to frontier (DTF), which measures the distance of each economy to the "frontier" representing the best performance observed on each of the indicators across all economies in the Doing Business sample since 2005. An economy's DTF is represented on a scale from 0 to 100 , where 0 represents the lowest performance and 100 represents the frontier. The ease of doing business ranking ranges from 1 to 190 . France ranks $31^{\text {st }}$, and performs lower than the average score of OECD Countries. ${ }^{19}$ Our results suggest that a possible explanation for the large regulation of private business may come from the relatively greater distrust of public sector workers towards the private sector.

This distrust may also have a negative impact on the judiciary. Most judges in French courts are civil servants. Cahuc and Carcillo (2012) show that judges distrust business and free market economy more than the rest of the population. Our results confirm this distrust of top civil servants against private business. They can also shed a new light on a regular debate concerning the identity of judges. In some particular courts (such as labor or commercial courts in France), judges are lay judges (i.e. they are not civil servants but representatives of employees and/or employers nominated by their peers). ${ }^{20}$ In many others countries, labor or commercial courts are composed of both lay and professional judges, or even only professional judges. An argument supporting lay judges could be to avoid the distrust of professional judges (who are civil servants) towards the private sector.

Third, the distrust of public sector workers towards the private sector could have a negative impact on cooperative projects such as public-private partnerships. These contracts aim at organizing a cooperation between public and private sector actors to build infrastructures and provide public services. Public-private partnerships combine the skills and resources of both the public and private sectors by sharing risks and responsibilities. Yet, the success of such partnerships depends on the ability of the two sectors to cooperate. For this reason, the World Bank has identified the cooperation and good governance between public and private actors as a key to successful public-

\footnotetext{
${ }^{18}$ More precisely, it provides quantitative indicators on regulation for starting a business, dealing with construction permits, getting electricity, registering property, obtaining loans, protecting minority investors, paying taxes, trading across borders, enforcing contracts, and resolving insolvency. Doing Business also measures features of labor market regulations.

${ }^{19}$ For comparison, Germany ranks $20^{\text {th }}$ and the UK is $7^{\text {th }}$. Source: http://www.doingbusiness.org/data/exploreeconomies/france

${ }^{20}$ For debates about judges' preferences in French labor courts, see Espinosa (2017); Desrieux and Espinosa (2017, 2018).
} 
private partnerships. ${ }^{21}$ As a consequence, distrust towards public-private partnerships could hurt such projects.

Finally, the results presented in this paper can also be read in an optimistic manner: students who propose to work in the public sector display the highest levels of trust in the public sector. Despite the lower wages proposed by the public sector, prospective civil servants devote their career to the public affairs because they believe that they can be useful to society in doing so. Overall, the strong motivation of prospective civil servants and their beliefs in their mission are two factors that might contribute to the well-functioning of the State.

\footnotetext{
${ }^{21}$ http://blogs.worldbank.org/ppps/good-decisions-successful-ppps
} 


\section{References}

Aghion, P., Algan, Y., Cahuc, P., and Shleifer, A. (2010). Regulation and distrust. The Quarterly Journal of Economics, 125(3):1015-1049.

Algan, Y. and Cahuc, P. (2014). Trust, Well-Being and Growth: New Evidence and Policy Implications. In Aghion, P. and Durlauf, S., editors, The Handbook of Economic Growth, pages 49-120. Elsevier Science.

Bafumi, J., Gelman, A., Park, D. K., and Kaplan, N. (2005). Practical issues in implementing and understanding bayesian ideal point estimation. Political Analysis, 3:171-197.

Banuri, S. and Keefer, P. (2016). Pro-social motivation, effort and the call to public service. European Economic Review, 83(C):139-164.

Bénabou, R. and Tirole, J. (2003). Intrinsic and extrinsic motivation. The Review of Economic Studies, 70(3):489-520.

Bénabou, R. and Tirole, J. (2006). Incentives and prosocial behavior. American Economic Review, 96(5):1652-1678.

Benabou, R. and Tirole, J. (2011). Laws and Norms. Nber working papers, National Bureau of Economic Research, Inc.

Brewer, G. (2003). Building social capital: Civic attitudes and behavior of public servants. Journal of Public Administration Research and Theory, 13:5-26.

Buurman, M., Delfgaauw, J., Dur, R., and Van den Bossche, S. (2012). Public sector employees: Risk averse and altruistic? Journal of Economic Behavior 83 Organization, 83(3):279-291.

Cahuc, P. and Algan, Y. (2009). Civic Virtue and Labor Market Institutions. American Economic Journal: Macroeconomics, 1(1):111-145.

Cahuc, P. and Carcillo, S. (2012). Les juges et l'économie: une défiance française. Technical report, Institut Montaigne.

Carlin, B., Dorobantu, F., and Viswanathan, S. (2009). Public trust, the law, and financial investment. Journal of Financial Economics, 92(3):321-341.

Carpenter, J., Doverspike, D., and Miguel, R. (2012). Public service motivation as a predictor of attraction to the public sector. Journal of Vocational Behavior, 80:509-523.

Chevallier, J. (2011). La place de l'administration dans la production des normes. Droit et société, (3):623-636.

Desrieux, C. and Espinosa, R. (2017). Enjeux et perspective de l'analyse économique des conseils de prud'hommes. Revue Française d'Économie, 23:137-168.

Desrieux, C. and Espinosa, R. (2018). Case Selection and Judicial Decision-Making: Evidence from French Labor Courts. Working Paper.

DeVaro, J., Maxwell, N., and Morita, H. (2017). Training and intrinsic motivation in nonprofit and for-profit organizations. Journal of Economic Behavior and Organization, 139(Supplement C):196 - 213 . 
Dur, R. and Zoutenbier, R. (2015). Intrinsic Motivations of Public Sector Employees: Evidence for Germany. German Economic Review, 16(3):343-366.

Espinosa, R. (2017). Constitutional Judicial Behavior: Exploring the Determinants of the Decisions of the French Constitutional Council. Review of Law and Economics, 13(2).

Gregg, P., Grout, P. A., Ratcliffe, A., Smith, S., and Windmeijer, F. (2011). How important is prosocial behaviour in the delivery of public services? Journal of Public Economics, 95(7-8):758-766.

Houston, D. (2006). "Walking the Walk" of Public Service Motivation: Public Employees and Charitable Gifts of Time, Blood, and Money. Journal of Public Administration Research and Theory, 16:67-86.

Kakinaka, M. and Kotani, K. (2011). An interplay between intrinsic and extrinsic motivations on voluntary contributions to a public good in a large economy. Public Choice, 147(1/2):29-41.

Leete, L. (2000). Wage equity and employee motivation in nonprofit and for-profit organizations. Journal of Economic Behavior and Organization, 43(4):423 - 446.

Martin, A. D. and Quinn, K. M. (2002). Dynamic ideal point estimation via markov chain monte carlo for the u.s. supreme court, 1953-1999. Political Analysis, 10:134-153.

Martin, A. D., Quinn, K. M., and Epstein, L. (2005). The median justice on the united states supreme court. North Carolina Law Review, 5:1275-1320.

Osterloh, M. and Frey, B. S. (2000). Motivation, knowledge transfer, and organizational forms. Organization Science, 11(5):538-550.

Saint-Paul, G. (2007). Le Rôle des Croyances et des Idéologies dans l'Économie Politique des Réformes. Revue d'Économie Politique, 117(4):577-592.

Saint-Paul, G. (2010). Endogenous Indoctrination: Occupational Choices, the Evolution of Beliefs and the Political Economy of Reforms. The Economic Journal, 120:325-353.

Vandenabeele, W. (2008). Government calling: Public service motivation as an element in selecting government as an employer of choice. Public Administration, 86:1089-1105. 


\section{A Tables}

Table 1: Sample size of respondents vs. overall student population.

\begin{tabular}{|c|c|c|c|c|c|}
\hline & \multicolumn{2}{|c|}{ All students } & \multicolumn{3}{|c|}{ "Only French students } \\
\hline & \multirow{2}{*}{$\begin{array}{l}\text { Overall } \\
\text { (1) }\end{array}$} & \multirow{2}{*}{$\begin{array}{c}\text { Respondents } \\
(2)\end{array}$} & \multirow{2}{*}{$\begin{array}{c}\text { Overall } \\
(3)\end{array}$} & \multicolumn{2}{|c|}{ Respondents } \\
\hline & & & & $\begin{array}{l}\text { All } \\
(4)\end{array}$ & $\begin{array}{c}\text { Career specified } \\
(5)\end{array}$ \\
\hline 1st year students & 933 & 287 & 794 & 261 & 155 \\
\hline 2nd year students & 2,587 & 243 & 831 & 228 & 131 \\
\hline 3rd year students & 1,046 & 2 & 940 & 0 & 0 \\
\hline 4th year students & 2,711 & 438 & 1,726 & 372 & 203 \\
\hline 5 th year students & 2,755 & 453 & 2,027 & 392 & 249 \\
\hline Other students & 10 & 0 & 5 & 0 & 0 \\
\hline Observations & 10,042 & 1,423 & 6,323 & 1,253 & 738 \\
\hline
\end{tabular}

Note: The table only includes students from the Le Havre and Paris campuses, and only College or Master's students. Third year students participate in a mandatory study abroad program, which explains why they did not participate in the survey. "Other students" includes Master's students who had a special status, and who were not registered in a specific year. 
Table 2: Descriptive statistics of respondents vs. overall student population, by Master's degree and admissions program.

\begin{tabular}{|c|c|c|c|c|c|}
\hline & \multicolumn{2}{|c|}{ All students } & \multicolumn{3}{|c|}{ "Only French students } \\
\hline & \multirow{2}{*}{$\begin{array}{l}\text { Overall } \\
\text { (1) }\end{array}$} & \multirow{2}{*}{$\begin{array}{c}\text { Respondents } \\
\text { (2) }\end{array}$} & \multirow{2}{*}{$\begin{array}{l}\text { Overall } \\
\text { (3) }\end{array}$} & \multicolumn{2}{|c|}{ Respondents } \\
\hline & & & & $\begin{array}{l}\text { All } \\
(4)\end{array}$ & $\begin{array}{c}\text { Career specified } \\
(5)\end{array}$ \\
\hline \multicolumn{6}{|c|}{ Panel A: Field of Master's degree (graduate students only) } \\
\hline Business & $12.64 \%$ & $13.13 \%$ & $15.49 \%$ & $13.87 \%$ & $13.27 \%$ \\
\hline Economics \& finance & $15.39 \%$ & $15.26 \%$ & $16.03 \%$ & $15.05 \%$ & $17.26 \%$ \\
\hline Environment & $1.77 \%$ & $2.47 \%$ & $1.70 \%$ & $2.49 \%$ & $2.21 \%$ \\
\hline European affairs & $4.58 \%$ & $3.37 \%$ & $3.84 \%$ & $2.62 \%$ & $3.10 \%$ \\
\hline History & $0.81 \%$ & $1.80 \%$ & $1.14 \%$ & $1.96 \%$ & $1.55 \%$ \\
\hline International Affairs & $20.27 \%$ & $18.52 \%$ & $11.82 \%$ & $14.53 \%$ & $11.73 \%$ \\
\hline Journalism & $1.66 \%$ & $1.80 \%$ & $2.07 \%$ & $1.83 \%$ & $0.66 \%$ \\
\hline Law & $8.65 \%$ & $9.88 \%$ & $10.28 \%$ & $9.82 \%$ & $10.18 \%$ \\
\hline Other & $6.08 \%$ & $0.00 \%$ & $0.47 \%$ & $0.00 \%$ & $0.00 \%$ \\
\hline Political science & $2.18 \%$ & $3.03 \%$ & $2.37 \%$ & $3.40 \%$ & $3.1 \%$ \\
\hline Public Affairs & $19.47 \%$ & $20.65 \%$ & $26.18 \%$ & $23.82 \%$ & $26.11 \%$ \\
\hline Sociology & $0.61 \%$ & $1.35 \%$ & $0.90 \%$ & $1.44 \%$ & $1.99 \%$ \\
\hline Urban & $5.89 \%$ & $8.75 \%$ & $7.71 \%$ & $9.16 \%$ & $8.85 \%$ \\
\hline Total & $100.00 \%$ & $100.00 \%$ & $100.00 \%$ & $100.00 \%$ & $100.00 \%$ \\
\hline Observations & 4,696 & 891 & 2,997 & 764 & 452 \\
\hline \multicolumn{6}{|c|}{ Panel B: Admissions program (all students) } \\
\hline Undergraduate national & $41.73 \%$ & $62.33 \%$ & $65.10 \%$ & $69.91 \%$ & $71.54 \%$ \\
\hline Undergraduate international & $9.28 \%$ & $9.49 \%$ & $5.80 \%$ & $5.59 \%$ & $4.47 \%$ \\
\hline Undergraduate priority & $6.45 \%$ & $8.29 \%$ & $9.77 \%$ & $9.18 \%$ & $8.94 \%$ \\
\hline International exchange & $18.65 \%$ & $0.07 \%$ & $0.60 \%$ & $0.00 \%$ & $0.00 \%$ \\
\hline Master's national & $10.50 \%$ & $12.02 \%$ & $15.42 \%$ & $13.01 \%$ & $12.60 \%$ \\
\hline Master's international & $10.58 \%$ & $6.89 \%$ & $2.56 \%$ & $2.08 \%$ & $2.17 \%$ \\
\hline Other & $2.81 \%$ & $0.91 \%$ & $0.74 \%$ & $0.24 \%$ & $0.27 \%$ \\
\hline Total & $100.00 \%$ & $100.00 \%$ & $100.00 \%$ & $100.00 \%$ & $100.00 \%$ \\
\hline Observations & 10,042 & 1,423 & 6,323 & 1,253 & 738 \\
\hline
\end{tabular}

Note: Panel A includes Master's degree students only. "Respondents" refers to students who at least started completing the survey. Some Master's level students were admitted as undergraduates, whereas others were admitted as undergraduates. "Career specified" refers to those students who completed the survey at least to the point where they indicated their intention to work in the public sector or not. Panels A and B do not include information on four French students who answered the survey: two were postgraduate students (one $\mathrm{PhD}$ and one preparing administrative exams), one was an undergraduate student on a campus that did not receive the survey, and one was an executive education student. Hence the total of French respondents is 1,253 students. 
Table 3: Descriptive statistics of reasons driving students to choose the private sector.

\begin{tabular}{llccccc}
\hline \hline $\begin{array}{l}\text { Want to take } \\
\text { public exams? }\end{array}$ & Reason & $\begin{array}{c}\text { Strongly } \\
\text { Disagree }\end{array}$ & Disagree & Indifferent & Agree & $\begin{array}{c}\text { Strongly } \\
\text { Agree }\end{array}$ \\
\hline \multirow{4}{*}{ Yes } & Competence & $10 \%$ & $33 \%$ & $29 \%$ & $23 \%$ & $5 \%$ \\
& Motivation & $10 \%$ & $25 \%$ & $30 \%$ & $28 \%$ & $7 \%$ \\
& Flexibility & $3 \%$ & $26 \%$ & $20 \%$ & $42 \%$ & $8 \%$ \\
& Entrepreneurship & $1 \%$ & $10 \%$ & $20 \%$ & $49 \%$ & $20 \%$ \\
& Wage & $0 \%$ & $1 \%$ & $2 \%$ & $40 \%$ & $57 \%$ \\
\multirow{5}{*}{ No } & Competence & $3 \%$ & $28 \%$ & $27 \%$ & $29 \%$ & $13 \%$ \\
& Motivation & $3 \%$ & $20 \%$ & $28 \%$ & $35 \%$ & $14 \%$ \\
& Flexibility & $3 \%$ & $31 \%$ & $15 \%$ & $38 \%$ & $13 \%$ \\
\hline \hline
\end{tabular}

Note: The sample of students consists of 304 respondents who declared their intention to become civil servants, and 435 who said the opposite.

Table 4: Perception of the factors driving students to choose the private sector according to the prospective sector of work.

\begin{tabular}{|c|c|c|c|c|}
\hline \multirow{2}{*}{ Reason } & \multicolumn{3}{|c|}{ Ordered Probit } & \multirow{2}{*}{$\frac{\text { Mean comparison }}{\mathrm{p} \text {-value }}$} \\
\hline & Estimated Effect & t-stat & $\mathrm{p}$-value & \\
\hline Wage & .111 & 1.247 & .212 & .107 \\
\hline Flexibility & -.029 & -.361 & .718 & .931 \\
\hline Entrepreneurship & -.322 & -3.981 & $<0.001$ & $<0.001$ \\
\hline Competence & -.416 & -5.268 & $<0.001$ & $<0.001$ \\
\hline Motivation & -.39 & -4.951 & $<0.001$ & $<0.001$ \\
\hline
\end{tabular}

The dependent variables are the listed reasons to work in the private sector. The independent variable is a dummy variable equal to 1 if the student plans to take a public sector exam.

Note: The sample of students consists of 304 respondents who declared their intention to become civil servants, and 435 who said the opposite. 
Table 5: Descriptive statistics of questions associated with Distrust in Companies

\begin{tabular}{|c|c|c|c|c|c|c|}
\hline $\begin{array}{l}\text { Want to take } \\
\text { public exams? }\end{array}$ & Reason & $\begin{array}{l}\text { Strongly } \\
\text { Disagree }\end{array}$ & Disagree & Indifferent & Agree & $\begin{array}{c}\text { Strongly } \\
\text { Agree }\end{array}$ \\
\hline \multirow{6}{*}{ Yes } & $\begin{array}{l}\text { Union representatives should benefit from } \\
\text { extra protection against being fired. }\end{array}$ & $14 \%$ & $24 \%$ & $8 \%$ & $35 \%$ & $18 \%$ \\
\hline & $\begin{array}{l}\text { Employees should have a stronger role in } \\
\text { the company's decision-making process. }\end{array}$ & $2 \%$ & $9 \%$ & $11 \%$ & $44 \%$ & $35 \%$ \\
\hline & $\begin{array}{l}\text { Controls of labor law enforcement are cur- } \\
\text { rently sufficient in France. }\end{array}$ & $13 \%$ & $39 \%$ & $21 \%$ & $22 \%$ & $5 \%$ \\
\hline & $\begin{array}{l}\text { Thresholds above which union representa- } \\
\text { tion becomes mandatory in the company } \\
\text { are too high. }\end{array}$ & $13 \%$ & $25 \%$ & $30 \%$ & $25 \%$ & $8 \%$ \\
\hline & $\begin{array}{l}\text { Layoffs should be banned when companies } \\
\text { make profits. }\end{array}$ & $16 \%$ & $30 \%$ & $12 \%$ & $31 \%$ & $11 \%$ \\
\hline & $\begin{array}{l}\text { The government should legislate to limit } \\
\text { employers' excessive remunerations. }\end{array}$ & $7 \%$ & $20 \%$ & $10 \%$ & $32 \%$ & $31 \%$ \\
\hline \multirow{6}{*}{ No } & $\begin{array}{l}\text { Union representatives should benefit from } \\
\text { extra protection against being fired. }\end{array}$ & $14 \%$ & $27 \%$ & $12 \%$ & $35 \%$ & $12 \%$ \\
\hline & $\begin{array}{l}\text { Employees should have a stronger role in } \\
\text { the company's decision-making process. }\end{array}$ & $2 \%$ & $8 \%$ & $11 \%$ & $45 \%$ & $33 \%$ \\
\hline & $\begin{array}{l}\text { Controls of labor law enforcement are cur- } \\
\text { rently sufficient in France. }\end{array}$ & $9 \%$ & $36 \%$ & $28 \%$ & $23 \%$ & $4 \%$ \\
\hline & $\begin{array}{l}\text { Thresholds above which union representa- } \\
\text { tion becomes mandatory in the company } \\
\text { are too high. }\end{array}$ & $10 \%$ & $25 \%$ & $33 \%$ & $24 \%$ & $8 \%$ \\
\hline & $\begin{array}{l}\text { Layoffs should be banned when companies } \\
\text { make profits. }\end{array}$ & $20 \%$ & $30 \%$ & $13 \%$ & $28 \%$ & $8 \%$ \\
\hline & $\begin{array}{l}\text { The government should legislate to limit } \\
\text { employers' excessive remunerations. }\end{array}$ & $12 \%$ & $16 \%$ & $15 \%$ & $33 \%$ & $24 \%$ \\
\hline
\end{tabular}

Note: The sample of students consists of 304 respondents who declared their intention to become civil servants, and 435 who said the opposite. 
Table 6: Descriptive statistics of questions associated with Easy to Conduct Business

\begin{tabular}{|c|c|c|c|c|c|c|}
\hline $\begin{array}{l}\text { Want to take } \\
\text { public exams? }\end{array}$ & Reason & $\begin{array}{l}\text { Strongly } \\
\text { Disagree }\end{array}$ & Disagree & Indifferent & Agree & $\begin{array}{l}\text { Strongly } \\
\text { Agree }\end{array}$ \\
\hline \multirow{7}{*}{ Yes } & $\begin{array}{l}\text { Procedures to fire an employee should be } \\
\text { made easier for the employer. }\end{array}$ & $16 \%$ & $31 \%$ & $14 \%$ & $31 \%$ & $9 \%$ \\
\hline & $\begin{array}{l}\text { It is currently easy to create a company in } \\
\text { France. }\end{array}$ & $12 \%$ & $43 \%$ & $16 \%$ & $25 \%$ & $4 \%$ \\
\hline & $\begin{array}{l}\text { Procedures to create a new business } \\
\text { should be made easier. }\end{array}$ & $1 \%$ & $6 \%$ & $17 \%$ & $43 \%$ & $33 \%$ \\
\hline & $\begin{array}{l}\text { Procedures to hire an employee should be } \\
\text { simplified. }\end{array}$ & $1 \%$ & $9 \%$ & $11 \%$ & $46 \%$ & $33 \%$ \\
\hline & $\begin{array}{l}\text { Labor costs are contributing to high un- } \\
\text { employment in France. }\end{array}$ & $8 \%$ & $27 \%$ & $9 \%$ & $38 \%$ & $19 \%$ \\
\hline & $\begin{array}{l}\text { It is currently easy to find funds to open a } \\
\text { business in France. }\end{array}$ & $9 \%$ & $42 \%$ & $20 \%$ & $25 \%$ & $4 \%$ \\
\hline & $\begin{array}{l}\text { It is currently easy for a young en- } \\
\text { trepreneur in France to obtain legal advice } \\
\text { and support to start a business. }\end{array}$ & $4 \%$ & $40 \%$ & $21 \%$ & $32 \%$ & $2 \%$ \\
\hline \multirow{7}{*}{ No } & $\begin{array}{l}\text { Procedures to fire an employee should be } \\
\text { made easier for the employer. }\end{array}$ & $9 \%$ & $26 \%$ & $20 \%$ & $32 \%$ & $12 \%$ \\
\hline & $\begin{array}{l}\text { It is currently easy to create a company in } \\
\text { France. }\end{array}$ & $16 \%$ & $44 \%$ & $13 \%$ & $23 \%$ & $5 \%$ \\
\hline & $\begin{array}{l}\text { Procedures to create a new business } \\
\text { should be made easier. }\end{array}$ & $1 \%$ & $3 \%$ & $15 \%$ & $43 \%$ & $38 \%$ \\
\hline & $\begin{array}{l}\text { Procedures to hire an employee should be } \\
\text { simplified. }\end{array}$ & $0 \%$ & $5 \%$ & $15 \%$ & $46 \%$ & $33 \%$ \\
\hline & $\begin{array}{l}\text { Labor is too costly, which currently con- } \\
\text { tributes to high unemployment in France. }\end{array}$ & $7 \%$ & $22 \%$ & $10 \%$ & $40 \%$ & $21 \%$ \\
\hline & $\begin{array}{l}\text { It is currently easy to find funds to open a } \\
\text { business in France. }\end{array}$ & $9 \%$ & $48 \%$ & $19 \%$ & $21 \%$ & $3 \%$ \\
\hline & $\begin{array}{l}\text { It is currently easy for a young en- } \\
\text { trepreneur in France to obtain legal advice } \\
\text { and support to start a business. }\end{array}$ & $6 \%$ & $39 \%$ & $26 \%$ & $26 \%$ & $3 \%$ \\
\hline
\end{tabular}

Note: The sample of students consists of 304 respondents who declared their intention to become civil servants, and 435 who said the opposite. 
Table 7: Attitudes towards the private sector according to the prospective sector of work.

\begin{tabular}{lccc}
\hline \hline Dimension & Private Sector & Public Sector & p-value \\
\hline Distrust in companies & -.014 & .097 & .088 \\
& $(.041)$ & $(.05)$ & \\
Easy to conduct business & -.067 & .084 & .017 \\
& $(.039)$ & $(.051)$ & \\
\hline \hline
\end{tabular}

Means in plain text, standard errors in parentheses. The p-value corresponds to a two-group mean comparison test.

Note: The sample of students consists of 304 respondents who declared their intention to become civil servants, and 435 who said the opposite.

Table 8: Descriptive statistics of questions associated with Provision of public goods.

\begin{tabular}{clcccc}
\hline \hline $\begin{array}{c}\text { Want to take } \\
\text { public exams? }\end{array}$ & Reason & Never & Sometimes & Most often & Always \\
\hline \multirow{6}{*}{ Yes } & Delegated Management & $9 \%$ & $31 \%$ & $48 \%$ & $12 \%$ \\
& Cost Reduction & $9 \%$ & $24 \%$ & $37 \%$ & $30 \%$ \\
& Innovation & $14 \%$ & $31 \%$ & $34 \%$ & $21 \%$ \\
& Quality Improvement & $18 \%$ & $38 \%$ & $29 \%$ & $16 \%$ \\
\hline \multirow{5}{*}{ No } & Delegated Management & $10 \%$ & $29 \%$ & $46 \%$ & $15 \%$ \\
& Cost Reduction & $12 \%$ & $22 \%$ & $34 \%$ & $33 \%$ \\
& Innovation & $10 \%$ & $29 \%$ & $30 \%$ & $30 \%$ \\
\hline \hline
\end{tabular}

Note: The sample of students consists of 277 respondents who declared their intention to become civil servants, and 385 who said the opposite. 
Table 9: Perception of private provision of public goods according to the prospective sector of work.

\begin{tabular}{lccccc}
\hline \hline \multirow{2}{*}{ Arguments for/against PPP } & \multicolumn{3}{c}{ Ordered Probit } & & Mean comparison \\
\cline { 2 - 3 } & Estimated Effect & t-stat & p-value & p-value \\
\hline Delegated Management & -.032 & -.381 & .703 & .745 \\
Reduce Cost & -.01 & -.121 & .903 & .956 \\
Foster Innovation & -.224 & -2.651 & .008 & .010 \\
Service Quality & -.209 & -2.479 & .013 & .012 \\
Legitimate Expropriation & .212 & 2.544 & .011 & .020 \\
Expropriation Compensation & -.109 & -1.313 & .189 & .239 \\
Engagements & -.204 & -1.067 & .286 & .286 \\
Nationalize & .682 & 3.163 & .002 & .002 \\
Vital Good & .301 & 1.446 & .148 & .149 \\
Devaluation & -.312 & -1.455 & .146 & .146 \\
\hline PCA & -.43 & -3.193 & .001 & .001 \\
\hline \hline
\end{tabular}

The dependent variables are the listed arguments in favor or against the use of Public-private partnerships (PPP). The independent variable is a dummy variable equal to 1 if the student plans to take a public exam.

Note: The sample of students consists of 304 respondents who declared their intention to become civil servants, and 435 who said the opposite.

Table 10: Descriptive statistics of levels of trust in institutions according to the prospective sector of work.

\begin{tabular}{lccccc}
\hline \hline \multirow{2}{*}{ Institution } & \multicolumn{3}{c}{ Intend to take exams for civil servants? } \\
\cline { 2 - 6 } & \multicolumn{3}{c}{ No } & \multicolumn{3}{c}{ Yes } & p-value \\
\hline National Assembly & 5.771 & $(.099)$ & 6.25 & $(.115)$ & .002 \\
Senate & 5.493 & $(.104)$ & 5.868 & $(.126)$ & .022 \\
Legal System & 6.734 & $(.094)$ & 6.928 & $(.107)$ & .179 \\
Police & 5.878 & $(.103)$ & 6.079 & $(.119)$ & .207 \\
Judges & 6.835 & $(.097)$ & 7.247 & $(.104)$ & .005 \\
Constitutional Council & 7.078 & $(.105)$ & 7.359 & $(.117)$ & .078 \\
Administrative Supreme Court & 6.826 & $(.103)$ & 7.385 & $(.104)$ & $<0.001$ \\
\hline PCA & 6.423 & $(.076)$ & 6.783 & $(.079)$ & .001 \\
\hline \hline
\end{tabular}

Means in plain text, standard errors in parentheses.

Note: The sample of students consists of 304 respondents who declared their intention to become civil servants, and 436 who said the opposite. 
Table 11: Descriptive statistics of reasons driving students to choose the public sector.

\begin{tabular}{llccccc}
\hline \hline $\begin{array}{l}\text { Want to take } \\
\text { public exams? }\end{array}$ & Reason & $\begin{array}{c}\text { Strongly } \\
\text { Disagree }\end{array}$ & Disagree & Indifferent & Agree & $\begin{array}{c}\text { Strongly } \\
\text { Agree }\end{array}$ \\
\hline \multirow{4}{*}{ Yes } & Lower Workload & $29 \%$ & $45 \%$ & $14 \%$ & $11 \%$ & $2 \%$ \\
& Easy Family & $13 \%$ & $30 \%$ & $22 \%$ & $29 \%$ & $6 \%$ \\
& Greater Security & $4 \%$ & $13 \%$ & $15 \%$ & $46 \%$ & $22 \%$ \\
& Social Gratification & $2 \%$ & $14 \%$ & $20 \%$ & $43 \%$ & $21 \%$ \\
& Change Society & $2 \%$ & $12 \%$ & $13 \%$ & $48 \%$ & $26 \%$ \\
& Satisfaction & $0 \%$ & $4 \%$ & $12 \%$ & $53 \%$ & $31 \%$ \\
\hline \multirow{5}{*}{ No } & Lower Workload & $18 \%$ & $41 \%$ & $22 \%$ & $16 \%$ & $3 \%$ \\
& Easy Family & $10 \%$ & $23 \%$ & $32 \%$ & $29 \%$ & $6 \%$ \\
& Greater Security & $3 \%$ & $11 \%$ & $13 \%$ & $49 \%$ & $24 \%$ \\
& Social Gratification & $2 \%$ & $13 \%$ & $23 \%$ & $45 \%$ & $17 \%$ \\
& Change Society & $4 \%$ & $17 \%$ & $17 \%$ & $48 \%$ & $15 \%$ \\
& Satisfaction & $1 \%$ & $7 \%$ & $18 \%$ & $51 \%$ & $22 \%$ \\
\hline \hline
\end{tabular}

Note: The sample of students consists of 304 respondents who declared their intention to become civil servants, and 436 who said the opposite.

Table 12: Perception of the factors driving students to choose the public sector according to the prospective sector of work.

\begin{tabular}{lccccc}
\hline \hline \multirow{2}{*}{ Reason } & \multicolumn{3}{c}{ Ordered Probit } & & Mean comparison \\
\cline { 2 - 3 } \cline { 5 - 5 } & Estimated Effect & t-stat & p-value & p-value \\
\hline Lower Workload & -.329 & -4.098 & $<0.001$ & & $<0.001$ \\
Easy Family & -.127 & -1.619 & .105 & .085 \\
Greater Security & -.103 & -1.284 & .199 & .178 \\
Social Gratification & .063 & .795 & .427 & .519 \\
Change Society & .334 & 4.142 & $<0.001$ & $<0.001$ \\
Public Affairs Satisfaction & .291 & 3.54 & $<0.001$ & $<0.001$ \\
\hline \hline
\end{tabular}

The dependent variables are the listed arguments in favor or against the use of Public-private partnerships (PPP). The independent variable is a dummy variable equal to 1 if the student plans to take a public exam.

Note: The sample of students consists of 304 respondents who declared their intention to become civil servants, and 436 who said the opposite. 
Table 13: Robustness check for the Common Source Bias: Results of regressions of the dependent variable (first column) on the proportion of students in the Master's program who end up working in the public sector.

\begin{tabular}{|c|c|c|c|}
\hline$\overline{\overline{\text { Dependent Variable }}}$ & Coefficient & T-stat & P-value \\
\hline Competent Teams & -.0042 & -.985 & 0.324 \\
\hline Motivation & -.0022 & -.479 & 0.632 \\
\hline Flexibility & .0038 & 1.009 & 0.313 \\
\hline Entrepreneurship & -.0048 & -1.668 & 0.095 \\
\hline Higher Wage & .0051 & 1.595 & 0.111 \\
\hline Protection of unionists & .0082 & 2.521 & 0.040 \\
\hline Participation of employees & .0045 & .674 & 0.522 \\
\hline Controls of law enforcement & .0019 & .631 & 0.548 \\
\hline Representation threshold & -.0023 & -.378 & 0.717 \\
\hline Limited firing if profits & .0007 & .077 & 0.941 \\
\hline Limitation of remuneration & .0079 & .844 & 0.426 \\
\hline Facilitation of firing & -.0092 & -1.509 & 0.175 \\
\hline Easy to create new firm & .0027 & 1.318 & 0.229 \\
\hline Facilitation of new firms & .0013 & .42 & 0.687 \\
\hline Facilitation of hiring & .0026 & 1.693 & 0.134 \\
\hline Labor is too costly & -.0044 & -.767 & 0.468 \\
\hline East to get funds & .0044 & .969 & 0.365 \\
\hline Easy to get counsel & .0024 & .901 & 0.398 \\
\hline Delegated Management & .0019 & .36 & 0.719 \\
\hline Service Quality & -.002 & -.298 & 0.765 \\
\hline Foster Innovation & -.0017 & -.332 & 0.740 \\
\hline Reduction of Costs & .0007 & .143 & 0.886 \\
\hline Legitimate Expropriation & .0117 & 2.124 & 0.034 \\
\hline Commitments & -.0078 & -.683 & 0.516 \\
\hline Nationalize & .026 & 2.505 & 0.041 \\
\hline Vital Good & .0186 & 1.667 & 0.140 \\
\hline Devaluation & .01 & .695 & 0.509 \\
\hline National Assembly & .022 & 3.408 & 0.011 \\
\hline Senate & .0251 & 4.158 & 0.004 \\
\hline Legal System & .0173 & 1.781 & 0.118 \\
\hline Police & .0121 & 1.331 & 0.225 \\
\hline Judges & .0202 & 2.444 & 0.045 \\
\hline Constitutional Council & .0199 & 1.622 & 0.149 \\
\hline Administrative Supreme Court & .0368 & 2.61 & 0.035 \\
\hline Greater Security & .0012 & .457 & 0.648 \\
\hline Public Affairs Satisfaction & .0132 & 5.601 & 0.648 \\
\hline Social Gratification & .0084 & 3.229 & 0.001 \\
\hline Change Society & .0108 & 5.89 & 0.000 \\
\hline Lower Workload & -.0105 & -1.867 & 0.062 \\
\hline Easy Family & .0015 & .337 & 0.736 \\
\hline
\end{tabular}

The coefficients correspond to the estimated difference between students who plan to work in the public sector relatively to those who want to work in the private sector. The econometric specification is either a linear model or an ordered choice model, depending on the nature of the dependent variable.

Note: Standard errors are clustered at the graduate school level. 


\section{B Ideal Points Estimates}

The Bayesian estimation of ideal points is usually referred to as the one dimensional item response theory. Such models were originally aimed at measuring students' performance on a test, and to locate them on a unique dimension. The original objective consisted in estimating three sets of parameters: $(i)$ an ability parameter for each student, $(i i)$ a difficulty parameter for each question of the test, and (iii) a discrimination parameter for each question. Bayesian methods were developed to discriminate students according to their ability, by taking into account questions' difficulty level, and by estimating their "relevance" to correctly discriminate students. ${ }^{22}$

These models have since been used in the political science literature, especially in the case of Supreme Court voting (Bafumi et al. (2005), Martin and Quinn (2002), Martin et al. (2005)), where researchers located Justices on a liberal-conservative dimension.

Our goal consists in estimating students' preferences on two dimensions (Distrust in Companies and Easy to do Business). To do so, we use the students' answers described in subsection 4.1.2. The possible answers to these questions had the following ordering: strongly disagree, slightly disagree, indifferent, slightly agree, strongly agree.

The model is defined by a logistic utility model, where the latent utility depends on both the questions' and students' parameters:

$$
y_{i j}^{*}=\alpha_{j} \theta_{i}+u_{i j}
$$

where $\alpha_{j}$ is the discrimination parameter of question $j, \theta_{i}$ is the score of individual $i$ on the estimated dimension, and $u_{i j}$ is a random component.

Given that we have five possible ordered answers, the associated observed choices are given by:

$$
\begin{aligned}
y_{i j} & =1 \text { if } y_{i j}^{*} \leq \phi_{1 j} \\
y_{i j} & =2 \text { if } y_{i j}^{*}>\phi_{1 j} \text { et } y_{i j}^{*} \leq \phi_{2 j} \\
\vdots & \\
y_{i j} & =5 \text { if } y_{i j}^{*}>\phi_{4, j}
\end{aligned}
$$

where $\phi_{j}$ is the vector of thresholds for the ordinal choice model.

The hyperpriors are set as follows:

$$
\begin{gathered}
\alpha_{j} \sim N\left(\mu_{\alpha}, \sigma_{\alpha}^{2}\right) \\
\phi_{j} \sim N\left(\mu_{\phi}, \sigma_{\phi}^{2}\right) \\
\theta_{i} \sim N(0,1) \\
\mu_{\alpha} \sim N(0,1) \text { and } \sigma_{\alpha} \sim \operatorname{Exp}(0.1) \\
\mu_{\phi} \sim N(0,1) \text { and } \sigma_{\phi} \sim \operatorname{Exp}(0.1)
\end{gathered}
$$

\footnotetext{
${ }^{22}$ Researchers anticipated the possibility that some questions could be correctly answered by low-skilled students and wrongly answered by high-skilled students.
} 
Given that we know a priori the correlation of the answers with the desired axes, we are able to reverse the order of the answers for the questions that are negatively correlated (see section 4.1.2). We use this information and overidentify the model by setting:

$$
\ln \left(\alpha_{j}\right) \sim N\left(\mu_{\alpha}, \sigma_{\alpha}^{2}\right)
$$




\section{Aspiring top civil servants' distrust in the private sector}

A. Boring, C. Desrieux and R. Espinosa

Online Appendix Questionnaire

\section{Partie 1 : Service public et secteur privé}

1. Sur une échelle de zéro à dix, quel est votre niveau de confiance dans les institutions suivantes ? [0 : aucune confiance, 10 : confiance totale]

- l'Assemblée Nationale ;

- le Sénat ;

- le système légal ;

- la police ;

- les juges ;

- le Conseil Constitutionnel ;

- le Conseil d'État.

2. Parmi les arguments suivants, quels sont ceux qui, à votre avis, motivent les individus à s'engager dans une carrière publique ? [1: pas du tout d'accord ; 2 : plutôt pas d'accord, 3 : indifférent, 4 : plutôt d'accord, 5 : tout à fait d'accord]

- Une plus grande sécurité de l'emploi ;

- Une plus grande satisfaction vis-à-vis de soi-même de s'occuper des affaires publiques ;

- Une plus grande gratification vis-à-vis d'autrui de s'occuper des affaires publiques ;

- La possibilité de changer la société ;

- Une charge de travail moins importante ;

- Une organisation facilitée de la vie familiale.

3. Parmi les arguments suivants, quels sont ceux qui, à votre avis, motivent les individus à exercer une activité dans le secteur privé ? [1: pas du tout d'accord ; 2 : plutôt pas d'accord, 3 : indifférent, 4 : plutôt d'accord, 5 : tout à fait d'accord]

- Un salaire plus élevé ;

- Une plus grande flexibilité du travail ;

- Un meilleur esprit d'entrepreneuriat;

- Des équipes plus compétentes ;

- Des équipes plus motivées dans leur travail.

4. Parmi les autres étudiants inscrits dans votre master et de destinant à la fonction publique, quels sont selon vous les facteurs déterminant ce choix de carrière? (Veuillez indiquer les trois facteurs les plus importants par ordre d'importance.)

- Le salaire ; 
- La sécurité de l'emploi ;

- La liberté d'entreprendre ;

- La charge de travail ;

- Le fait d'être utile à la société ;

- La reconnaissance sociale ;

- L'ambition politique ;

- L'équilibre de la vie familiale.

5. Pensez-vous que certains postes de fonctionnaires ne sont pas compatibles avec un mandat politique ? [1: Non, aucun ; 2 : Oui, mais une minorité seulement ; 3 : Oui, la plupart ; 4 : Oui, tous]

6. Pensez-vous que cela soit plus facile pour un fonctionnaire d'occuper un mandat d'élu que pour un salarié ? [1: pas du tout d'accord ; 2 : plutôt pas d'accord, 3 : indifférent, 4 : plutôt d'accord, 5 : tout à fait d'accord]

7. Pensez-vous que les fonctionnaires soient les plus qualifiés pour occuper des fonctions politiques ? [1: pas du tout d'accord ; 2 : plutôt pas d'accord, 3 : indifférent, 4 : plutôt d'accord, 5 : tout à fait d'accord]

\section{Partie 2 : Relations sociales au travail}

1. D’un point de vue personnel, vous paraît-il justifié qu'un délégué syndical bénéficie d'une protection renforcée par rapport aux autres salariés, notamment en matière licenciement ? [1 : pas du tout d'accord ; 2 : plutôt pas d'accord, 3 : indifférent, 4 : plutôt d'accord, 5 : tout à fait d'accord]

2. D'un point de vue personnel, vous paraît-il nécessaire aujourd'hui de renforcer les pouvoirs du salarié dans la prise de décision en entreprise (par exemple, par un renforcement de leur participation dans les conseils d'administration) ? [1 : pas du tout d'accord ; 2 : plutôt pas d'accord, 3 : indifférent, 4 : plutôt d'accord, 5 : tout à fait d'accord]

3. La justice prud'homale est aujourd'hui organisée autour des syndicats : les conseillers prud'homaux sont des individus élus par les salariés et par les chefs d'entreprise pour les représenter et trancher les litiges provenant de conflits individuels au travail. Ce système vous semble-t-il juste ? [1: pas du tout d'accord ; 2 : plutôt pas d'accord, 3 : indifférent, 4 : plutôt d'accord, 5 : tout à fait d'accord]

4. Pensez-vous à titre personnel qu'il existe assez de contrôles de l'application du droit du travail en France (ex : inspection du travail) ? [1: pas du tout d'accord ; 2 : plutôt pas d'accord, 3 : indifférent, 4 : plutôt d'accord, 5 : tout à fait d'accord]

5. Pensez-vous à titre personnel qu'il faille abaisser les seuls au-delà desquels une représentation syndicale en entreprise est obligatoire ? [1: pas du tout d'accord ; 2 : plutôt pas d'accord, 3 : indifférent, 4 : plutôt d'accord, 5 : tout à fait d'accord]

6. Pensez-vous à titre personnel que les procédures de licenciement devraient être allégées ? [1 : pas du tout d'accord ; 2 : plutôt pas d'accord, 3 : indifférent, $4:$ plutôt d'accord, 5 : tout à fait d'accord] 
7. Pensez-vous à titre personnel qu'il faudrait introduire une interdiction des licenciements lorsque les entreprises enregistrent des résultats positifs ? [1: pas du tout d'accord ; 2 : plutôt pas d'accord, 3 : indifférent, 4 : plutôt d'accord, 5 : tout à fait d'accord]

8. Pensez-vous à titre personnel que, pour certains salariés, le seul moyen d'obtenir une rémunération équitable passe par les grèves ? [1: pas du tout d'accord ; 2 : plutôt pas d'accord, 3 : indifférent, 4 : plutôt d'accord, 5 : tout à fait d'accord]

\section{Partie 3 : Économie d'entreprise}

1. Pensez-vous à titre personnel qu'il soit facile de créer une entreprise en France aujourd'hui ? [1: pas du tout d'accord ; 2 : plutôt pas d'accord, 3 : indifférent, $4:$ plutôt d'accord, 5 : tout à fait d'accord]

2. Pensez-vous à titre personnel que les procédures administratives de création d'entreprises devraient être allégées ? [1: pas du tout d'accord ; 2 : plutôt pas d'accord, 3 : indifférent, 4 : plutôt d'accord, 5 : tout à fait d'accord]

3. Pensez-vous à titre personnel que les procédures d'embauche des salariés devraient être allégées ? [1 : pas du tout d'accord ; 2 : plutôt pas d'accord, 3 : indifférent, 4 : plutôt d'accord, 5 : tout à fait d'accord]

4. Pensez-vous à titre personnel que le coût du travail -et notamment le paiement des charges sociales- soit un frein à l'emploi en France aujourd'hui ? [1 : pas du tout d'accord ; 2 : plutôt pas d'accord, 3 : indifférent, $4:$ plutôt d'accord, 5 : tout à fait d'accord]

5. Pensez-vous à titre personnel qu'il soit aisé de trouver des financements pour créer une entreprise dans un secteur innovant en France ? [1: pas du tout d'accord ; 2 : plutôt pas d'accord, 3 : indifférent, $4:$ plutôt d'accord, 5 : tout à fait d'accord]

6. Pensez-vous à titre personnel qu'il soit facile pour les entrepreneurs de se reconvertir en cas d'échec de leur projet ? [1: pas du tout d'accord ; 2 : plutôt pas d'accord, 3 : indifférent, 4 : plutôt d'accord, 5 : tout à fait d'accord]

7. Pensez-vous à titre personnel qu'un jeune entrepreneur peut facilement être conseillé et entouré dans ses démarches de création d'entreprise? [1: pas du tout d'accord ; 2 : plutôt pas d'accord, 3 : indifférent, 4 : plutôt d'accord, 5 : tout à fait d'accord]

8. Pensez-vous à titre personnel que le gouvernement devrait intervenir pour empêcher les chefs d'entreprises de recevoir des salaires excessifs ? [1: pas du tout d'accord ; 2 : plutôt pas d'accord, 3 : indifférent, 4 : plutôt d'accord, 5 : tout à fait d'accord]

\section{Partie 4 : Carrière et orientation}

1. Envisagez-vous de passer les concours de la fonction publique ? [0: Non ; 1 : Oui]

2. Pensez-vous à moyen terme vous présenter pour un mandat politique ? [1: Absolument pas ; 2 : Il y a peu de chances ; 3 : Probablement ; 4 : Tout à fait] 
3. D'un point de vue personnel, quels facteurs influencent vos choix de carrière ? (Premier facteur, deuxième facteur, troisième facteur)

- Le salaire ;

- La sécurité de l'emploi ;

- La liberté d'entreprendre ;

- La charge de travail ;

- Le fait d'être utile à la société ;

- La reconnaissance sociale ;

- L'ambition politique ;

- L'équilibre de la vie familiale.

4. Êtes-vous membre d'un parti politique ? [0: Non ; 1 : Oui]

5. Militez-vous à Sciences Po ? [0 : Non ; 1 : Oui]

6. Êtes-vous membre d'un syndicat à Sciences Po ? [0 : Non ; 1 : Oui]

7. Êtes-vous membre d'une association Sciences Po ? (Hors parti, hors syndicat) [0 : Non ; 1 : Oui]

\section{Partie 5 : Cas pratique PPP}

Énoncé On parle de gestion directe d'un service public local (distribution d'eau, collecte des déchets, approvisionnement des cantines scolaires, etc...) lorsque la collectivité locale concernée assure elle-même l'exploitation et la gestion de ce service. C'est une structure publique (une régie publique) qui assure le service. On parle de gestion déléguée lorsque la collectivité confie ce service à une entreprise, généralement privée, qui opère sous son contrôle. Le choix de l'entreprise privée se réalise le plus souvent par appel d'offres ce qui implique une mise en concurrence des candidats à la gestion du service.

1. D’un point de vue personnel, diriez-vous que la gestion déléguée est une bonne chose ? [1 : Non, pratiquement jamais ; 2 : Oui, mais dans quelques cas seulement ; 3 : Oui, dans la plupart des cas ; 4 : Oui, dans la majorité des cas]

2. Recourir à un contrat avec une entreprise privée pur gérer un service local vous paraît-il un moyen de... [1: Non, pratiquement jamais ; 2 : Oui, mais dans quelques cas seulement ; 3 : Oui, dans la plupart des cas ; 4 : Oui, dans la majorité des cas]

- Réduire les coûts de gestion ;

- Encourager l'innovation ;

- Améliorer la qualité des services. 
Énoncé Consignes Les questions ci-dessous vous proposent d'analyser un cas relatif à un contrat entre une partie publique et une partie privée. Dans un premier temps, le cas vous est décrit de manière succinte, vous apportant les éléments nécessaires à la compréhension du litige qui oppose les parties. Ensuite, vous serez amené à répondre à plusieurs questions liées au cas. La plupart des questions sont sujettes à interprétation, si bien qu'il n'existe pas de "bonne" ou de "mauvaise" réponse : n'hésitez donc pas à donner votre avis.

Présentation du cas Considérons une autorité gouvernementale qui établit un contrat de concession avec une entreprise privée étrangère afin d'assurer la distribution de l'eau auprès de sa population. Cette entreprise emprunte en dollars pour réaliser les investissements nécessaires au contrat de concession. Quelques années plus tard, la monnaie du pays est dévaluée par décision du gouvernement, ce qui cause un important problème de rentabilité à l'entreprise privée : elle perçoit ses recettes en monnaie locale et a des charges en dollars, liées à son emprunt. L'entreprise demande alors à l'autorité gouvernementale une autorisation pour augmenter le prix de l'eau de $10 \%$ pour combler une partie de ses recettes manquantes. Le gouvernement refuse la réévaluation du prix. L'entreprise ne peut plus poursuivre ses investissements, et certains foyers ne parviennent pas à se faire raccorder aux réseaux de distribution d'eau. Excédée par ces problèmes de distribution d'eau à toute la population, l'autorité gouvernementale décide unilatéralement de mettre fin au contrat (avant son terme) en expropriant l'entreprise de ses investissements.

3. D'un point de vue purement personnel, pensez-vous que la décision d'expropriation de l'État était justifiée ? [1: pas du tout d'accord ; 2 : plutôt pas d'accord, 3 : indifférent, 4 : plutôt d'accord, 5 : tout à fait d'accord]

4. Si vous aviez la possibilité d'indemniser l'entreprise investisseuse, vous proposeriez d'indemniser à hauteur de (une seule réponse possible) :

- Aucune indemnité ;

- Une partie de l'investissement ;

- L'intégralité de l'investissement ;

- L'intégralité de l'investissement et une partie des profits escomptés ;

- L'intégralité de l'investissement et la totalité des profits escomptés ;

- L'intégralité de l'investissement, la totalité des profits escomptés et des dommages punitifs.

Énoncé Arbitrage Afin de contester les décisions de l'Etat, l'entreprise investisseuse saisit une cour d'arbitrage internationale spécialisée ainsi que le droit de l'Etat concerné l'avait prévu lors de la signature du contrat.

5. À votre avis, quelle importance convient-il d'attributer à chacun des arguments suivants pour résoudre le litige ? [0 : aucune importance ; 10 : essentiel à la résolution du litige]

- L'Etat doit respecter ses engagements vis-à-vis de l'entreprise investisseuse et lui garantir la pérennité de ses actifs.

- L'Etat doit pouvoir nationaliser les secteurs qu'il estime essentiels au développement économique de son pays. 
- L'eau est un "bien" vital qui justifie de conférer à l'Etat des pouvoirs exceptionnels, quitte à ne pas respecter ses engagements contractuels.

- La dévaluation de la monnaie est un motif légitime pour l'entreprise investisseuse pour demander la réévaluation du prix : il s'agit d'une décision de l'Etat et dont les conséquences doivent être supportées par l'Etat.

6. De manière générale, pensez-vous que l'intérêt général puisse être apprécié par un tribunal arbitral ? [1: Non, pratiquement jamais ; 2 : Oui, mais dans quelques cas seulement ; 3 : Oui, dans la plupart des cas ; 4 : Oui, dans la majorité des cas] 